\title{
RECEIVED
}

DEC 222000

OST,

\section{Deployment Plan for Bioremediation and Natural Attenuation for In Situ Restoration of Chloroethene-Contaminated Groundwater}

\author{
L. N. Peterson \\ R. C. Starr \\ K. S. Sorenson \\ R. W. Smith \\ T. J. Phelps
}

Published March 1999

Idaho National Engineering and Environmental Laboratory Applied Engineering Development Laboratory Lockheed Martin Idaho Technologies Company Idaho Falls, Idaho 83415

Prepared for the

U.S. Department of Energy Assistant Secretary for Environmental Management Under DOE Idaho Operations Office Contract DE-AC07-94ID13223 


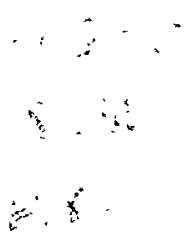




\section{DISCLAIMER}

This report was prepared as an account of work sponsored by an agency of the United States Government. Neither the United States Government nor any agency thereof, nor any of their employees, make any warranty, express or implied, or assumes any legal liability or responsibility for the accuracy, completeness, or usefulness of any information, apparatus, product, or process disclosed, or represents that its use would not infringe privately owned rights. Reference herein to any specific commercial product, process, or service by trade name, trademark, manufacturer, or otherwise does not necessarily constitute or imply its endorsement, recommendation, or favoring by the United States Government or any agency thereof. The views and opinions of authors expressed herein do not necessarily state or reflect those of the United States Government or any agency thereof. 


\section{DISCLAIMER}

\section{Portions of this document may be illegible in electronic image products. Images are produced from the best available original document.}


INEEL/EXT-99-00167

Revision 0

March 1999

\section{Deployment Plan for Bioremediation and Natural Attenuation for In Situ Restoration of Chloroethene-Contaminated Groundwater}

Approved by:
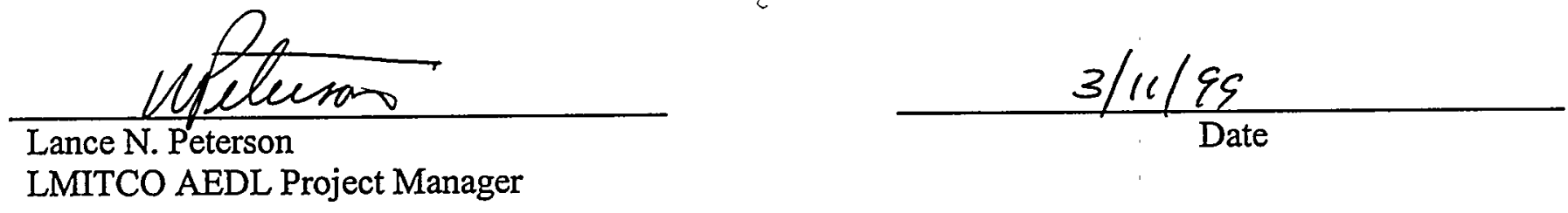


\section{ABSTRACT}

This deployment plan describes a project funded by the Accelerated Site Technology Deployment Program of the U.S. Department of Energy (DOE). The objective is to facilitate deployment of enhanced in situ bioremediation (ISB) and monitored natural attenuation (MNA) of chloroethene-contaminated groundwater to DOE sites. Enhanced ISB accelerates dechlorination of chloroethenes under anaerobic conditions by providing nutrients to the microbial community. Natural attenuation does not require nutrient addition. Enhanced ISB in the upgradient portion of a contaminant plume coupled with MNA in the downgradient portion is being implemented at Test Area North (TAN) at the Idaho National Engineering and Environmental Laboratory. Selected DOE sites will be screened to assess their suitability for enhanced ISB/MNA. Tasks include: (1) characterization of the TAN microbial community and correlation of community characteristics with chloroethene degradation ability, (2) installation of wells to facilitate evaluation of MNA at TAN, (3) monitoring to better delineate MNA at TAN, and (4) screening of selected other DOE sites for suitability of ISB/MNA, and limited supplemental characterization. Data evaluation will provide a sound technical basis for decision makers to consider use of enhanced ISB and MNA, alone or together, as remedial technologies for these sites. 


\section{CONTENTS}

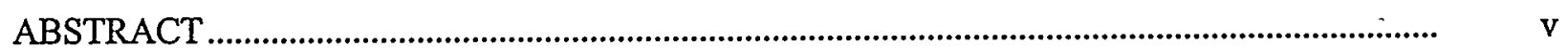

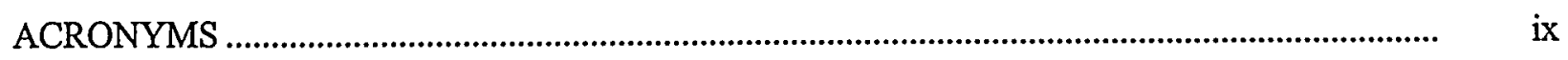

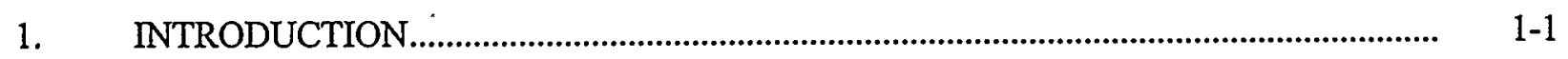

$1.1 \quad$ ASTD Program Objectives ....................................................................... $\quad 1-1$

1.2 Deployment Project Objectives......................................................................... $1-2$

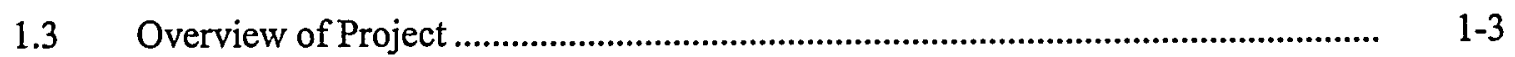

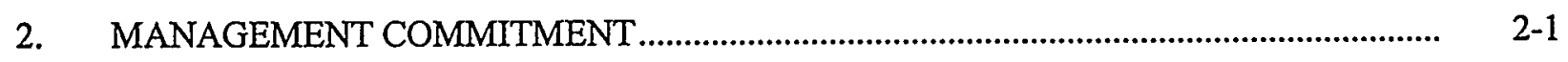

2.1 Implementing Site Commitment ................................................................... 2-1

2.2 Deployment Site Commitment..................................................................... 2-2

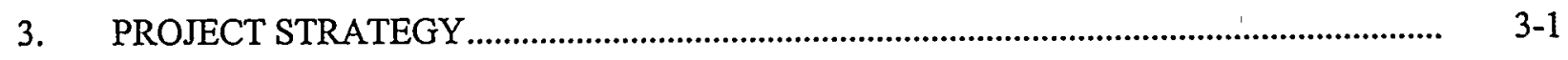

$3.1 \quad$ Project Profile...........................................................................................

$3.2 \quad$ Qualification Strategy ..................................................................................... $3-3$

3.3 Implementation Strategy ................................................................................

$3.4 \quad$ Deployment Strategy ...................................................................................... $\quad 3-4$

3.5 Measures of Success .....................................................................................

3.5.1 Technical Success ........................................................................... $3-4$

3.5.2 Financial Success ........................................................................... $3-4$

3.5.3 Deployment Success ......................................................................... $\quad 3-6$

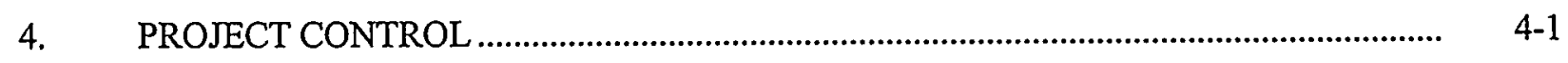

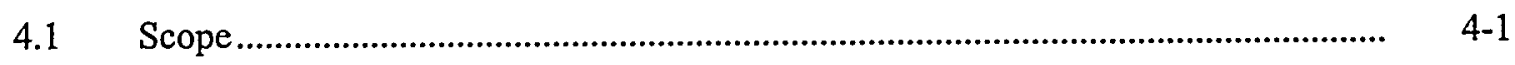

4.1.1 Task 1: Microbial Community Characterization......................................... 4-1

4.1.2 Task 2: Natural Attenuation Well Installation .......................................... 4-3

4.1.3 Task 3: Natural Attenuation Monitoring .................................................... 4-3

4.1.4 Task 4: Technology Integration and Deployment Process Linkage .......... . 4-7

4.1.5 Deployment at Sites B and C .................................................................. $4-9$

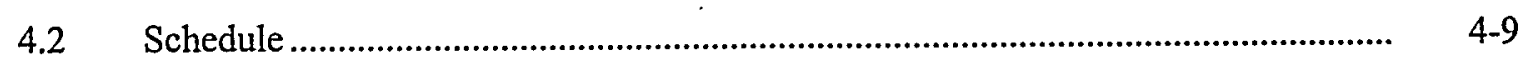

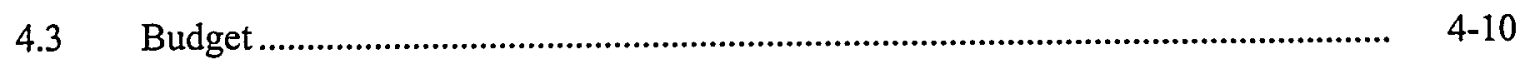


4.4 Reporting, Deliverables, and Milestones .......................................................... 4-11

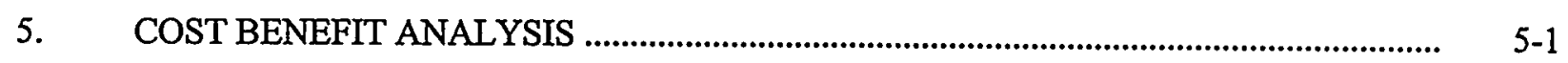

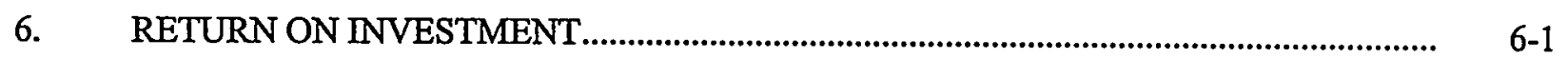



Appendix A-Authorization Letter From ASTD Program

Appendix B - Cost Estimate Spreadsheets

Appendix C-Letters of Commitment from Implementing and Deploying Sites

Appendix D-Project Tables

Appendix E-Schedule and Logic Diagrams

\section{FIGURES}

4-1. Location of TAN TCE plume and five new natural attenuation wells................................... $4-4$

4-2. Generalized completion log for new natural attenuation well. ............................................ 4-5

4-3. Implementation schedule for the enhanced ISB/MNA project and a comparison

to the CERCLA baseline schedule.

\section{TABLES}

3-1. Technical performance measures for deployment of enhanced ISB/MNA........................ $3-5$

4-1. Summary of the planning budget for deployment of enhanced ISB/MNA.........................

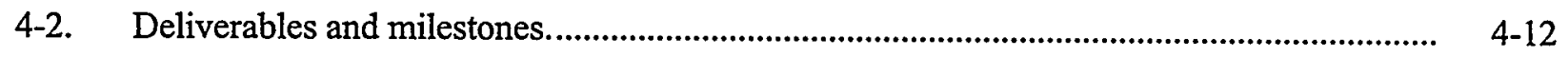

5-1. Current baseline estimate for deployment of pump and treat at three sites. ....................... $5-1$

5-2. ASTD cost estimate for deployment of ISB/MNA at three sites. ...................................... $5-2$

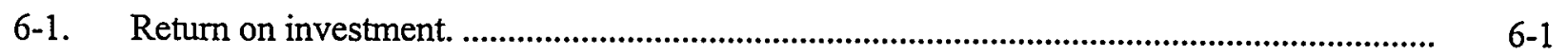




\section{ACRONYMS}

\begin{tabular}{|c|c|}
\hline AEDL & Applied Engineering Development Laboratory \\
\hline ASTD & Accelerated Site Technology Deployment \\
\hline CERCLA & $\begin{array}{l}\text { Comprehensive Environmental Response, Compensation, } \\
\text { and Liability Act }\end{array}$ \\
\hline DCE & dichloroethene \\
\hline DOE & U.S. Department of Energy \\
\hline DOE-ID & U.S. Department of Energy Idaho Operations Office \\
\hline EM & environmental management \\
\hline EPA & U.S. Environmental Protection Agency \\
\hline ER & environmental restoration \\
\hline FEWP & field evaluation work plan \\
\hline FY & fiscal year \\
\hline INEEL & Idaho National Engineering and Environmental Laboratory \\
\hline ISB & in situ bioremediation \\
\hline ITRC & Interstate Technology Regulatory Cooperation \\
\hline LMITCO & Lockheed Martin Idaho Technologies Company \\
\hline MNA & monitored natural attenuation \\
\hline MPN & most probable number \\
\hline OU & operable unit \\
\hline PCE & tetrachloroethene \\
\hline PCR & polymerase chain reactions \\
\hline PLFA & phospholipid fatty acids \\
\hline $\mathrm{RD} / \mathrm{RA}$ & remedial design/remedial action \\
\hline ROD & Record of Decision \\
\hline ROI & return on investment \\
\hline
\end{tabular}




$\begin{array}{ll}\text { RTDF } & \text { Remedial Technologies Development Forum } \\ \text { SLB } & \text { signature lipid biomarkers } \\ \text { TAN } & \text { Test Area North } \\ \text { TCE } & \text { trichloroethene } \\ \text { TTP } & \text { Technical Task Plan } \\ \text { TYP } & \text { Ten-year Plan } \\ \text { VOC } & \text { volatile organic compound }\end{array}$




\section{Deployment Plan \\ Bioremediation and Natural Attenuation for In Situ Restoration of Chloroethene-Contaminated Groundwater (Draft)}

\section{INTRODUCTION}

This deployment plan was prepared following guidance published on the Accelerated Site Technology Deployment (ASTD) program internet web page (U.S. Department of Energy [DOE] June 9, 1997, DOE, Office of Science and Technology, Technology Deployment Initiative, Deployment Plan Guidance Document [http://infoshare.inel.gov/astd/deployment]). The enhanced in situ bioremediation (ISB) and monitored natural attenuation (MNA) deployment project was described in a proposal submitted by the Idaho National Engineering and Environmental Laboratory (INEEL) to the ASTD program in June 1998 (INEEL 1998). This deployment plan was prepared following notification that the proposed scope of work had been approved by the ASTD program (see Appendix A).

Following approval of this enhanced ISB/MNA deployment plan by the ASTD program office, a Technical Task Plan (TTP) will be prepared, and the INEEL Applied Engineering Development Laboratory (AEDL) baseline will be modified in accordance with the scope of work described in this deployment plan.

\subsection{ASTD Program Objectives}

The ASTD program objectives focus on coordinated and efficient deployment of technologies that reduce cleanup cost and promote reinvestment of cost savings at participating sites. The programmatic ASTD objectives include:

- $\quad$ Provide multiple deployment of technologies or processes to conduct cleanup (environmental restoration [ER], waste management, decontamination and decommissioning, etc.) in such a way as to reduce DOE Office of Environmental Management (EM) cleanup costs and support the Ten-year Plan (TYP) (Accelerating Cleanup: Paths to Closure (DOE 1998) goals

- Provide third-party validation of cost savings

- Create an incentive for multiple site participation through reinvestment of cost savings

- Break down barriers that prohibit implementation of technologies or processes

- Achieve closer technology implementation coordination through joint ownership and funding across the DOE EM organizations.

This ASTD deployment project is designed to address each of the programmatic objectives. 


\subsection{Deployment Project Objectives}

The enhanced ISB/MNA project strategy includes implementing combined in situ bioremediation and monitored natural attenuation technologies at the INEEL Test Area North (TAN) facility and subsequently deploying the combined or individual technologies at two additional DOE sites. Based on cost estimates prepared for INEEL, successful application of this technology will result in a substantial cost savings (reduction by a factor of 2) relative to the current baseline. The implementation at TAN will be coordinated with Comprehensive Environmental Response, Compensation, and Liability Act (CERCLA) post-Record of Decision (ROD) technology field evaluations and will be subject to regulatory agency review and concurrence prior to formal acceptance as a final remedial technology. It is reasonable to assume that similar cost savings and regulatory agency review will apply to subsequent deployments at other participating DOE sites.

The enhanced ISB/MNA project objectives have been designed to support ASTD programmatic objectives as described below.

\subsubsection{Project Objective: Reduce Remediation Cost for Chloroethene-Contaminated Groundwater}

Overall reduction in the EM mortgage for DOE ER activities is one goal stated in the Ten-year Plan (DOE 1998). Chapter 4 of the TYP, Meeting Programmatic Challenges, identifies the application of science and deployment of technology as key tools for reducing life-cycle costs of the EM cleanup program (p 4-8). The enhanced ISB/MNA deployment project is based on the results of technology evaluations conducted by EM- 40 over the past two years. These evaluations have documented the potential cost savings to be derived from the deployment of ISB/MNA at TAN. The existing evaluations meet the requirements of the ASTD qualification process (laboratory scale). The objective for the implementation step at the INEEL will be to collect field scale process data to support a thorough evaluation of life-cycle costs. The life cycle cost analysis will be made available for third party validation.

\subsubsection{Project Objective: Validate Cost Reduction}

Individual ASTD deployment plan tasks (see Section 4) will be coordinated with EM-40 funded activities to provide sufficient field and process data to allow third-party validation of cost savings at the implementing site. The deployment sites will incorporate field and process data collection strategies developed at the INEEL implementing site. Third party validated cost savings will be reinvested at the respective sites.

\subsubsection{Project Objective: Remove Barriers to Technology Implementation}

Common barriers to application of new technologies include the lack of field-scale performance and cost data needed to rationally evaluate the feasibility of applying a technology at a particular site. The enhanced ISB/MNA project will produce performance and cost data for field-scale application at the INEEL to facilitate evaluation of the technology for application at additional sites. It should be noted that the hydrogeologic conditions at the INEEL include a relatively deep contaminated zone, 200 to $400 \mathrm{ft}$ below ground surface within a fractured rock aquifer. These conditions are among the more difficult for remediating chloroethene contamination. Successful implementation at the INEEL will provide a sound technical basis and implementation strategy for deployment at other sites. 
An additional barrier to application of new technologies is the general lack of familiarity that comes with the early full-scale implementations of any new technology. Federal and state regulatory agency personnel responsible for overseeing ER activities for the INEEL TAN groundwater plume will be actively involved in the initial implementation. This involvement will begin the transfer of information to the decision maker community to facilitate acceptance of enhanced ISB/MNA. Presentation of the results of the implementation at technical symposia, in the peer-reviewed literature, and at workshops for decision makers will facilitate further acceptance of the technology by both the technical and decision maker communities.

\subsubsection{Project Objective: Coordination and Joint Ownership of Deployment}

The project will achieve closer coordination through joint ownership and funding across the DOE EM organizations by integrating EM-40 CERCLA activities with supporting tasks defined in this deployment plan. The integrated activities allow leveraging of EM-40 and EM-50 funds to support combined programmatic objectives. Implementation of the technology at one site (INEEL) allows leveraging of process design and data collection strategies for more streamlined implementation at subsequent deployment sites.

This project will also capitalize on ongoing basic and applied research activities at TAN funded by the EM Science Program and the Office of Technology Development. These organizations implement directed field research projects (at no cost to ASTD or EM-40) to provide the fundamental scientific understanding of subsurface microbial ecology and its relationship to site hydrology and biogeochemistry necessary to ensure successful implementation of enhanced ISB/MNA. The techniques and scientific understanding developed through these programs will facilitate subsequent deployment of the technology at other sites.

\subsection{Overview of Project}

This project consists of implementing enhanced ISB/MNA in a spatially coupled treatment train as an active restoration technology for contaminated groundwater at the INEEL. The implementation will be followed by qualification of enhanced ISB/MNA at two other DOE sites. Subsequent deployment of enhanced ISB/MNA at the two qualified sites will be funded by EM-40. Qualification is defined as the process of determining, based on existing data (possibly augmented by limited collection of additional data), whether a particular contaminated zone is amenable to enhanced ISB, MNA, or a combination of these technologies. Implementation is defined as performing a set of activities that provide field scale data to optimize and validate the performance of ISB/MNA at a particular site. Deployment is defined as the process of evaluating optimization and validation data collected during the implementation step, completing the decision process for regulatory selection of enhanced ISB/MNA as the final remediation strategy, and executing long-term field-scale restoration activities.

The qualification process has been completed for the TAN contaminant plume at the INEEL and will be performed for additional deployment sites as a part of this deployment plan. The INEEL will be the implementing site and two additional sites will be selected for further qualification (funded by ASTD) and implementation and deployment (funded by EM-40).

The project described in this deployment plan is an enhancement to the on-going EM-40 funded CERCLA project at the INEEL. The EM-50 funded enhancements include: (1) proving the ability of a microbial community characterization technique to identify communities that have the ability to degrade chloroethenes by comparison to conventional microbial characterization techniques; (2) improving the evaluation of monitored natural attenuation as a remedial technology for TAN by installing additional 
monitoring wells, purchasing a system for collecting depth-discrete samples from uncased boreholes, and collection, analysis, and interpretation of depth-discrete samples; and (3) qualification of enhanced ISB/MNA as remedial technologies for two other DOE sites. Due to the focused nature of CERCLA remediation and to limited funding, these specific activities would not be possible without support from the ASTD program. 


\section{MANAGEMENT COMMITMENT}

Technology implementation at the INEEL is led by the U.S. Department of Energy Idaho Operations Office (DOE-ID) ER program manager, Ms. Kathleen E. Hain. Ms. Hain has the overall responsibility for and authority to commit the necessary facilities and resources to the project. Formal communications, commitments, and reporting between participating field offices and the ASTD office at DOE-ID are the responsibility of the Federal Program Manager. The Lockheed Martin Idaho Technologies Company (LMITCO) ER program manager, K.L. Falconer, has full authority to command necessary resources within LMITCO to execute the project. The LMITCO Project Manager is responsible for execution of all technical and facility activities necessary to implement the project. Deployment team support is provided by LMITCO engineering, regulatory, and public participation organizations that routinely support facility, program, and technology deployment projects.

\subsection{Implementing Site Commitment}

The INEEL will function as the ASTD implementing site. The implementation location will be the Test Area North trichloroethene (TCE) groundwater plume. This area is a designated CERCLA site, Operable Unit (OU) 1-07B, and is currently in the post-ROD remedial design/remedial action (RD/RA) cleanup phase of CERCLA remediation.

As the implementing site, INEEL and DOE-ID have demonstrated commitment to this ASTD project through modification of the baseline to incorporate the proposed activity. Modification will be accomplished in several steps to correspond with the ASTD funding strategy. The first baseline change was completed in January 1999 with allocation of $10 \%(\$ 37.5 \mathrm{~K})$ of the enhanced ISB/MNA proposal award total for FY 1999 ( $\$ 375 \mathrm{~K})$ to cover costs of Deployment Plan preparation. The planned schedule for baseline change to incorporate the full award amount is as follows:

- January 1999: Approved Funding Plan supplemental allocation of $\$ 37.5 \mathrm{~K}$ for preparation of the Deployment Plan

- March 1999: Following ASTD approval of the Deployment Plan, submit Technical Task Plan (TTP) to allocate full FY 1999 proposal award amount $(\$ 375 \mathrm{~K})$ from the ASTD program

- April 1999: Modification of AEDL baseline following ASTD approval of the TTP

- July 1999: $\quad$ Revise enhanced ISB/MNA TTP for FY 2000 request for funding

- October 1999: Modify baseline following ASTD approval of FY 2000 TTP revision

- July 2000: $\quad$ Revise enhanced ISB/MNA TTP for FY 2001 request for funding

- October 2000: Modify baseline following ASTD approval of FY 2001 TTP revision.

Further commitment of the implementing site management team for support of the enhanced ISB/MNA deployment is demonstrated by the dedication of $\$ 525 \mathrm{~K}$ EM-40 matching funds to partially cover the cost of Task 2 (natural attenuation monitoring well installation) as defined in Section 4 below. In addition, EM-40 has contributed $\$ 172 \mathrm{~K}$ in support of the ISB field evaluation report and $\$ 187 \mathrm{~K}$ for preparation of the MNA field evaluation report. These two reports will present the verification and validation data analysis for regulatory agency review of enhanced ISB/MNA. These funds have been 
incorporated into the CERCLA project baseline and activities are underway to integrate installation of two natural attenuation monitoring wells with FY 1999 ASTD project scope. Appendix B includes a copy of the approved CERCLA project baseline demonstrating commitment of EM-40 matching funds.

\subsection{Deployment Site Commitment}

Four DOE sites have expressed an interest in participating in enhanced ISB/MNA deployment following completion of the implementation step at INEEL. The four sites and corresponding contacts are:

Participating Site

Lawrence Livermore National Laboratory

Oak Ridge National Laboratory

Paducah Site

Portsmouth Site

\section{Deployment Contact}

Mr. Mike Brown

(925) 423-7061

mike.brown@oak.doe.gov

Ms. Elizabeth Phillips

(423) 241-6172

ezp@ornl.gov.

Mr. John Sheppard

(502) 441-6804

sheppardjd@ornl.gov

Ms. Kristy Wiehle

(740) $897-5020$

Each of the sites has provided a letter of commitment (see Appendix C) and will be invited to participate in a Site Qualification Workshop to be held at the INEEL. Two sites will be selected for sequential qualification, implementation, and deployment as described in Section 3 below. ASTD funding will be used to support each site's participation in the workshop and additional funding will be made available to support limited characterization activity needed to fill data gaps identified during the site qualification workshop. 


\section{PROJECT STRATEGY}

The scientific and technical merit of ISB has been well documented over the past 10 years (Hinchee, 1991, 1993, 1995, Alleman and Leeson 1997). In situ bioremediation has grown from an early recognition of application, and later active endorsement, as a remedial technology for petroleum hydrocarbons (California Senate Bill 1764 Advisory Committee 1996), to the current recognition as a remedial technology for the more recalcitrant chlorinated hydrocarbons.

Enhanced ISB for the more oxidized chlorinated solvents (i.e., tetrachloroethene [PCE] and TCE) generally relies on the process of anaerobic reductive dechlorination. Chloroethenes act as electron acceptors for microbially mediated reactions in which chlorine atoms are sequentially replaced with hydrogen atoms under anaerobic conditions. Thus, PCE is reduced to TCE, which is reduced to 1,2-dichloroethene (DCE), which is reduced to vinyl chloride, which is reduced to ethene. A sufficient electron donor source is the primary requirement to facilitate this reaction.

The anaerobic reductive dechlorination process was first demonstrated for TCE in the laboratory in the early 1980s. Before 1990 it was shown that the process could transform PCE and TCE completely to the innocuous product, ethene. In the early 1990s many field sites were identified at which anaerobic reductive dechlorination of TCE was occurring intrinsically due to the presence of co-contaminants such as fuel hydrocarbons that acted as electron donors to drive the reaction. One of the most well-known is the St. Joseph, Michigan site where TCE concentrations were reduced 24-fold without any amendment of groundwater. Other publicized sites where TCE transformation to ethene without enhancement has been observed include Plattsburgh Air Force Base and Dover Air Force Base. Enhanced ISB of TCE through anaerobic reductive dechlorination has been demonstrated in the field through the U.S. Environmental Protection Agency (EPA) Site program. Concentrations of TCE in groundwater were reduced by over an order of magnitude in less than one year by adding lactate to a treatment cell at a site in Watertown, Massachusetts.

The source area at TAN is an ideal place for deployment of enhanced ISB because it is relatively small spatially and because anaerobic reductive dechlorination appears to be occurring intrinsically. The area is already anaerobic, has significant concentrations of 1,2-DCE (predominantly the cis-DCE isomer), has trace concentrations of vinyl chloride and ethene, and has a small electron donor source from the codisposed sludge. In addition, laboratory studies with indigenous microbes from the TAN subsurface have shown that the microbial consortium is capable of carrying out complete anaerobic reductive dechlorination at rates equal to or faster than most published in the literature. It was also shown that the reaction rate was enhanced substantially by increasing the available electron donor. Thus, enhanced ISB at TAN has a high probability of successful qualification and long-term deployment.

As with enhanced ISB, MNA first became recognized as a remedial option for petroleum hydrocarbons. This recognition culminated in the writing of protocols for evaluating the process such as the Technical Protocol for Implementing Intrinsic Remediation with Long-term Monitoring for Natural Attenuation of Fuel Contamination Dissolved in Groundwater (Air Force Center for Environmental Excellence 1995). As the observation of natural attenuation of chlorinated solvents through anaerobic reductive dechlorination became more common, they were included in protocols such as the Technical Protocol for Evaluating Natural Attenuation of Chlorinated Solvents in Groundwater (EPA 1998), which is based on the Air Force Center for Environmental Excellence (1996) protocol. In addition to the protocols listed, the American Society for Testing and Materials and the Remediation Technology Development Forum are currently writing protocols. The EPA has issued an Interim Final Directive on the Use of Monitored Natural Attenuation at Superfund, RCRA Corrective Action, and Underground Storage Tank Sites (EPA 1997). It is noted in the Directive that the use of MNA as a component of groundwater remediation goes back as far as 1985. 
An important element in the application of MNA is adequate site characterization to demonstrate the efficacy of the approach at a given site. While it has been demonstrated that anaerobic reductive dechlorination is occurring in the source area at TAN, this process is not sufficient by itself to restore the site. The integration of MNA of the dissolved plume with enhanced ISB at the source area, however, will achieve remedial action objectives if the aggregate attenuation rate in the dissolved plume is sufficient. Field attenuation rates can be estimated using several methods based on the concentration decrease of a contaminant with distance from the source along a flow line. Attenuation rate estimates for TCE in the TAN dissolved plume give half-lives ranging from 8 to 20 years. Assuming a 20-year half-life with dispersion, simulations predict that MNA would meet remedial action objectives for that part of the plume having TCE concentrations below $5,000 \mu \mathrm{g} / \mathrm{L}$. The enhanced ISB treatment cell will be designed to remediate TCE concentrations of $2,000 \mu \mathrm{g} / \mathrm{L}$ or greater. Thus, the integration of these approaches is expected to meet remedial action objectives for the entire plume.

It is noted in the EPA Directive that "in general, the level of site characterization to support a comprehensive evaluation of NA is more detailed than that needed to support active remediation." Hence, the need to drill additional monitoring wells will confirm the analysis performed to date in support of the deployment of MNA at TAN. It is also noted in the EPA Directive that "where biodegradation will be assessed, characterization also should include evaluation of the nutrients and electron donors and acceptors present in the groundwater, the concentrations of co-metabolites and metabolic by-products, and perhaps specific analyses to identify the microbial populations present." Because biodegradation is likely to be an important part of NA at least in the portion of the dissolved plume near the enhanced ISB treatment cell, this proposal includes the monitoring and characterization discussed in the EPA Directive and in technical protocols.

\subsection{Project Profile}

The ASTD enhanced ISB/MNA project will implement an integrated and cost leveraged strategy of qualification, implementation, and deployment at three DOE sites. The profile includes deployment at the following DOE sites:

- Site A: The implementing site will be the INEEL

- $\quad$ Site B: To be selected at the Site Qualification Workshop (LLNL, ORNL, Paducah, or Portsmouth)

- $\quad$ Site C: To be selected at the Site Qualification Workshop (LLNL, ORNL, Paducah, or Portsmouth).

The deployment project profile is sequential with implementation activity conducted at INEEL occurring in FY 1999, qualification of sites B and C in FY 2000 and 2001 respectively, and deployment (as a component of the CERCLA decision process) scheduled to follow completion of qualification and implementation activities at each site.

Qualification is defined as the process of determining, based on existing data (possibly augmented by limited collection of new data), whether or not a particular site or OU is amenable to enhanced in situ bioremediation, monitored natural attenuation, or a combination of the two technologies. The qualification step is largely focused on completing a site selection process to insure a high probability of success at any site chosen for implementation and deployment. Implementation is defined as the process of conducting a well defined set of activities that provide field scale data to optimize and validate the enhanced ISB/MNA process at a given site. Implementation at INEEL is currently underway at TAN and 
completion of field data collection is planned for first quarter FY 2000. Deployment is defined as the process of evaluating optimization and validation data collected during the implementation step, completing the decision process for regulatory selection of enhanced ISB/MNA as the final remediation strategy, and executing long-term field-scale restoration activities.

Deployment will be funded entirely by EM-40 and will normally be a component of a CERCLA ROD RD/RA restoration activity. Deployment at the INEEL will begin in FY 2000 with the preparation of the enhanced ISB/MNA field evaluation report. The report will be prepared for regulatory agency review and comment to support an agency decision process for selection of enhanced ISB/MNA (singly or in combination) as the final restoration technology.

\subsection{Qualification Strategy}

Qualification, the process of determining if a particular site or OU is amenable to enhanced in situ bioremediation, monitored natural attenuation, or a combination of the two technologies, has been completed for the INEEL TAN OU 1-07B groundwater plume (Site A). The results of the qualification process are presented in the ISB Field Evaluation Work Plan (FEWP) and supporting documents (DOE-ID 1997, 1998a, 1998b; LMITCO 1998a, 1998b, 1998c, 1998d). Successful qualification of the TAN chloroethene groundwater plume has shown that anaerobic chloroethene biodegradation is occurring in the vicinity of the source area, and empirical evidence indicates that chloroethene degradation is occurring in the aerobic distal portion of the plume.

Qualification of Site B and Site C will be conducted in a manner analogous to the process used at TAN. During FY 1999 up to four DOE sites will receive financial support under this ASTD deployment plan to participate in a Site Qualification Workshop at the INEEL. Fiscal Year (FY) 1999 ASTD funding is limited, and hence EM-40 may be requested to provide matching funds to support the candidate deployment sites' participation. Each site will review the INEEL TAN ISB FEWP and present their current analysis of existing data in a similar fashion at the workshop. The workshop is planned for the April-June time frame subject to ASTD approval of this deployment plan and modification of the baseline to incorporate scope and budget defined by this plan. The INEEL implementation team will review the site qualification data presented and select the two sites that are best suited for use of enhanced ISB/MNA as remedial technologies. One site (Site B) will be selected for further qualification activity in FY 2000. Additional characterization data deemed necessary to fill identified data gaps at Site B may be collected as the first step of the implementation process. ASTD funding will be made available to support this additional site characterization activity. Depending on the scope of additional characterization activity, EM-40 matching funds from participating sites may be required. Further qualification of a second site (Site C) will be sequenced to begin in FY 2001 and may also include collection of additional characterization data.

\subsection{Implementation Strategy}

Implementation, the process of conducting a well defined set of activities that provide data to validate that the field scale enhanced ISB/MNA process is working at a given site, is currently underway at the INEEL TAN site. The FY 1999 implementation is funded $80 \%$ through EM-40 and 20\% through

this ASTD deployment plan. The results of the INEEL TAN implementation activity will be compiled in a field evaluation report during the first quarter of FY 2000.

Implementation at Sites $B$ and $C$ will be sequential with the first beginning in FY 2000 and the second in FY 2001. Funding for implementation at Sites B and C will be provided by EM-40, while the 
ASTD deployment plan will support the INEEL implementation team to provide assistance as requested by the Site $\mathrm{B}$ or $\mathrm{C}$ implementation team.

\subsection{Deployment Strategy}

Deployment, the process of evaluating optimization and validation data collected during the implementation step, completing the decision process for regulatory selection of enhanced ISB/MNA as the final remediation strategy, and executing long-term field-scale restoration activities, is currently incorporated in the INEEL TAN OU 1-07B baseline. This process begins with preparation of a field evaluation report for regulatory agency review. Subject to regulatory review and selection of enhanced ISB/MNA (singly or in combination), the controlling Record of Decision will be amended to reflect the agencies' decision for the final plume restoration remedy. Funding of the deployment process for the INEEL TAN OU 1-07B groundwater plume is provided entirely by EM-40.

Deployment at Sites B and C will be sequential with the first beginning in FY 2002 and the second in FY 2003. Funding for deployment at Sites B and C will also be provided by EM-40. The ASTD deployment plan may continue to support the INEEL deployment team to provide assistance as requested by the Site $B$ or $C$ deployment teams. Cost savings realized by the implementation and deployment of enhanced ISB/MNA at Sites B and C will be reinvested at each site respectively.

\subsection{Measures of Success}

Successful deployment of enhanced ISB/MNA can be monitored using incremental and overall performance measures. These measures are conveniently divided into three separate categories: (1) Technical Success, (2) Financial Success, and (3) Deployment Success. Specific measures appropriate to each category are presented below.

\subsubsection{Technical Success}

Technical success will be achieved by comparing the ability of the phospholipid fatty acids (PLFA) microbial community characterization technique to identify chloroethene degrader communities to that of deoxyribonucleic acid(s) (DNA) probe microbial community characterization techniques (Task 1), by comparing the measured rate of natural attenuation to the rate (determined from modeling) needed for MNA to be a suitable remedial technology (Tasks 2 and 3), and by collecting and interpreting data for qualifying enhanced ISB/MNA at two other DOE sites (Task 4).

The ASTD program can measure progress toward technical success by tracking and evaluating key components of the deployment process. As these components are implemented, specific technical performance measures can be evaluated. Table 3-1 identifies the key components of the deployment along with associated technical performance measures.

The project tables presented in Appendix D will be included in monthly reports and will document incremental progress and final attainment of technical performance measures.

\subsubsection{Financial Success}

Financial success is measured during the deployment process by tracking project schedule and budget. Monthly reports will contain. schedule status, budgeted cost of work scheduled, budgeted cost of work performed, and actual cost of work performed performance measures. Maintaining a $+1-10 \%$ project variance will constitute financial success during the qualification and implementation stages of the 
Table 3-1. Technical performance measures for deployment of enhanced ISB/MNA.

\begin{tabular}{|c|c|c|c|}
\hline Task & $\begin{array}{l}\text { Deployment } \\
\text { Component }\end{array}$ & $\begin{array}{l}\text { Performance } \\
\text { Measure }\end{array}$ & Description \\
\hline \multirow[t]{2}{*}{1} & \multirow[t]{2}{*}{$\begin{array}{l}\text { Microbial community } \\
\text { characterization. }\end{array}$} & PM 1 & $\begin{array}{l}\text { PLFA, PCR, and SLB samples collected, analyzed, and } \\
\text { interpreted. }\end{array}$ \\
\hline & & PM 2 & $\begin{array}{l}\text { Microbial biomass analyses indicate the presence and, } \\
\text { where desired, enrichment of microbes that facilitate } \\
\text { degradation of chlorinated solvents. }\end{array}$ \\
\hline \multirow[t]{2}{*}{2} & \multirow{2}{*}{$\begin{array}{l}\text { Installation of natural } \\
\text { attenuation monitoring } \\
\text { wells at INEEL }\end{array}$} & PM 3 & $\begin{array}{l}\text { New wells for assessing natural attenuation in the dissolved } \\
\text { plume at TAN are installed with EM-40 funding. }\end{array}$ \\
\hline & & PM 4 & $\begin{array}{l}\text { New wells for assessing natural attenuation in the dissolved } \\
\text { plume at TAN are installed with ASTD funding. }\end{array}$ \\
\hline \multirow[t]{5}{*}{3} & \multirow[t]{5}{*}{$\begin{array}{l}\text { Natural Attenuation } \\
\text { Monitoring }\end{array}$} & PM 5 & $\begin{array}{l}\text { Depth-discrete sampling system designed, fabricated, and } \\
\text { delivered. }\end{array}$ \\
\hline & & PM 6 & Depth-discrete samples collected and analyzed. \\
\hline & & PM 7 & $\begin{array}{l}\text { Calculation of mass flux through plume transects is } \\
\text { facilitated. }\end{array}$ \\
\hline & & PM 8 & $\begin{array}{l}\text { Spatial and temporal trends in concentration can be } \\
\text { evaluated. }\end{array}$ \\
\hline & & PM 9 & $\begin{array}{l}\text { Dissolved plume degradation rates can be calculated, and } \\
\text { indicate that remedial action objectives can be met. }\end{array}$ \\
\hline
\end{tabular}

4 Technology Integration and Deployment Process Linkage
4.1 Technical performance monitoring and Monitoring Regulatory/Stakeh older Involvement
4.2 Data Analysis and Qualification

PM 10 Project plans and results presented to regulatory and stakeholder organizations

PM 11 ISB biweekly monitoring data sets are collected, analyzed, and interpreted.

PM 12 Geochemical conditions in the enhanced ISB zone are successfully manipulated

PM 13 Nutrient amendment increases biological activity.

PM 14 The flux of dissolved contaminants out of the secondary source area is reduced.

PM 15 The rate of ARD calculated from the field data indicate that cleanup will be accelerated relative to the baseline technology, pump-and-treat.
4.3 Site Selection and Qualification
PM 16 Site qualification workshop held and Deployment Sites B and $\mathrm{C}$ selected.
PM 17 Qualification data gaps, if any, filled.
PM 18 Qualification data presented to agencies for consideration of ISB/MNA as a remedial approach.


project. Once the deployment stage is reached, financial success will be monitored through the EM-40 project management process and will no longer be reported to the ASTD program office. A key element of the ASTD financial performance measure will be third party validation of proposed cost savings. The proposed cost savings will be estimated from process and field data collected during the implementation of enhanced ISB/MNA at the INEEL. As a result, the cost savings performance measure will be addressed in the second year of the deployment process.

In summary, the main elements of performance measure for financial success are:

- Maintaining acceptable project schedule and project budget variance $( \pm 10 \%)$

- Third party validation of proposed cost savings (50\% reduction in remediation costs relative to the baseline)

- Life cycle cost savings generated following deployment of technology (based on ROI)

- $\quad$ Cost savings reinvested to further accelerate cleanup at participating sites.

\subsubsection{Deployment Success}

The clear and unambiguous measure of deployment success is regulatory acceptance of the technology either by incorporating the technology in a ROD that specifies a final remediation process or through amendment of an existing ROD to replace a previously selected remedy. Issuance or amendment of a ROD will include regulatory agency review of performance data generated to support evaluation of technical and financial success and will be a component of a decision making process that will take place within the EM-40 CERCLA cleanup process. The ASTD program must measure deployment plan success on the basis of technical and financial evaluation strategies presented above. Actual deployment of enhanced ISB/MNA at participating sites will take place outside the ASTD-funded portion of the deployment project. The ASTD deployment participants will define site specific performance measures to assess the following overall deployment goals:

- Deployment technology selected in CERCLA ROD or amended ROD

- Deployment site cleanup goals were achieved

- Cleanup activity was completed ahead of the baseline schedule

- Complex-wide technology utilization issues were resolved

- Stakeholders were actively associated with deployment. 


\section{PROJECT CONTROL}

The overall enhanced ISB/MNA deployment will be managed by the INEEL project team. Qualification and implementation activities at sites $\mathrm{B}$ and $\mathrm{C}$ will be managed by project teams at those sites. This deployment plan documents the life-cycle baseline that will be used to implement technology deployment and monitor performance. Baseline performance measures are, as always, tied to the annual funding cycle and are subject to revision, should adequate funding be delayed or unavailable. The ASTD project managers will receive monthly status reports that will address the specific performance metrics defined in Section 3.5 and will present updated Project Tables as defined in the Deployment Plan Guidance Document (http://infoshare.inel.gov/astd/deployment). Monthly status reports will include appropriate input from sites $B$ and $C$ and will be prepared by the INEEL project team. The remainder of this section addresses the specific scope, schedule and budget baseline for the enhanced ISB/MNA deployment project.

\subsection{Scope}

The four tasks described in Section 2 of the enhanced ISB/MNA proposal (INEEL 1998) have been carefully integrated with the EM-40 funded CERCLA. RD/RA groundwater restoration project currently underway at TAN. The project life cycle scope includes independent ASTD activities and coordinated EM-50/EM-40 activities that support deployment to other DOE sites. The detailed life cycle scope for each of the ASTD funded tasks is described below.

\subsubsection{Task 1: Microbial Community Characterization}

Microbial characterization techniques will be used at the TAN TCE plume to test the ability of a screening technique, PLFA analysis, to identify microbial communities that can degrade chloroethenes. The results of PLFA characterization will be compared to the results obtained using DNA microbial community characterization techniques. The objectives are to: (1) observe the spatial and temporal differences in the microbial community due to contaminant and nutrient amendment concentrations; and (2) identify microbial communities that have the ability to degrade chloroethenes. If PLFA and/or the DNA probe techniques can be used to reliably discriminate between communities that are or are not capable of degrading chloroethenes, they can be used for preliminary assessments of microbial communities that are faster and less expensive than assessments made using conventional techniques. Assuming that these techniques have the requisite discriminating ability, they may be used in the qualification stage at deployment sites B and C.

One of the first steps in qualifying a site for use of enhanced ISB/MNA for chloroethene remediation, as well as to monitor remediation progress over time, is to determine if the indigenous microbial community contains sufficient populations capable of transforming the chloroethenes present at the site into the desired daughter products. The traditional approach, laboratory microcosm studies, is time consuming and expensive, and may be confounded by the inability to grow the relevant microorganisms in the laboratory that are important under field conditions. An alternative approach that is faster and less expensive is to characterize the microbial community using a suite of techniques that analyze for specific biomarkers of degrader populations. These techniques include genomic analyses employing polymerase chain reactions (PCR) that amplify genomic signatures and enable verification that degrader microorganisms are present. Combining this technique with dilutions, as in classic most probable number (MPN) analyses, provides order-of-magnitude estimates of population levels of specific targeted degrader populations. Although highly specific, these molecular analyses are poorly scalable, time consuming and still require a significant population density for detection (approximately 100,000 of the targeted microbes are required for a good determination). A less specific but robust and highly 
scalable technique involves analysis of microbial membranes, specifically the PLFA present in the membranes of all living cells. These analyses give a snapshot of the types of microbial populations present in a community as well as identification of unique signature lipid biomarkers (SLB) present in specific microorganisms.

Combining the PLFA and SLB lipid analyses with PCR and genomic characterizations provides qualitative estimates of microbial biomass, diversity and estimates of specific microorganisms bearing unique lipid or genomic signatures. Continued monitoring of the in situ microbial community over time at TAN will provide time series snapshots of the extant microbial community, and its changes following nutrient amendment. This data will facilitate a decision regarding long-term implementation of ISB if a proliferation of populations of chloroethene degrading microorganisms corresponds to decreases in contaminant concentrations. For example, lipid analyses and positive PCR genomic tests substantiated by MPN determinations revealed a five order of increase during an aerobic ISB treatment at the Savannah River Site.

Expanding this work from TAN and applying it at deployment sites B and C, as well as additional sites beyond the scope of this project, will be simpler, cheaper, more advanced, and more specific, in part from experience gained at TAN and in large measure from scientific advancements in data interpretation and more sensitive molecular techniques.

Microbial community characterization at TAN will include the following tasks:

Task 1.1-Collection of Quarterly Samples from ARD Zone

- $\quad$ Activity 1.1a: Sample 5 wells during January 1999

- $\quad$ Activity 1.1b: Sample 5 wells during March 1999

- $\quad$ Activity 1.1c: Sample 5 wells during June 1999

- Activity 1.1d: Sample 5 wells during September 1999

Task 1.2-Collection of Quarterly Samples from Medial Zone

- Activity 1.2a: Sample 8 wells during October 1999

- $\quad$ Activity 1.2b: Sample 8 wells during January 2000

- $\quad$ Activity 1.2c: Sample 8 wells during April 2000

- Activity 1.2d: Sample 8 wells during July 2000

Task 1.3-Conduct PLFA, SLB, and PCR Analysis

- $\quad$ Activity 1.3a: FY 1999 Microbial Characterization Analysis

- Activity 1.3b: FY 2000 Microbial Characterization Analysis

Task 1.4-Analyze Results and Prepare Report 
- $\quad$ Activity 1.4a: FY 1999 Microbial Characterization Report (November 1999)

- $\quad$ Activity 1.4b: FY 2000 Microbial Characterization Report (September 2000).

\subsubsection{Task 2: Natural Attenuation Monitoring Well Installation}

The ASTD proposal identified installation of wells to support evaluation of natural attenuation in the distal zone of the TAN groundwater plume. The OU 1-07B CERCLA project is currently planning installation of two wells in FY 1999 and one additional well in FY 2000. The three wells to be installed in FY 1999 and FY 2000 will be funded by EM-40 matching funds, and two additional wells will be funded through the FY 2000 ASTD program. The FY 1999 NA wells have been designated PNA-2 and PNA-4. The FY 2000 EM-40 funded NA well has been designated PNA-1 and the EM-50 funded wells are PNA-3 and PNA-5. The locations of the five wells are shown in Figure 4-1 and a generalized completion diagram is shown in Figure 4-2. The scope for this task will be managed by the CERCLA $\mathrm{RD} / \mathrm{RA}$ project team and well installation status will be included in the ASTD monthly report.

\section{Task 2.1-Installation of EM-40 Funded Natural Attenuation Monitoring Wells}

- $\quad$ Activity 2.1a: Drill and complete PNA-4

- $\quad$ Activity 2.1b: Drill and complete PNA-2

- Activity 2.1c: Drill and complete PNA-1

Task 2.2-Installation of EM-50 Funded Natural Attenuation Monitoring Wells

- $\quad$ Activity 2.2a: Drill and complete PNA-3

- $\quad$ Activity 2.2b: Drill and complete PNA-5.

\subsubsection{Task 3: Natural Attenuation Monitoring}

The scope for this task includes monitoring activities in the distal zone of the plume. The monitoring will focus on depth-discrete sampling to determine the vertical distribution of contaminants and indicator parameters used to develop the "Lines of Evidence" that support an evaluation of natural attenuation. The first activity will be to acquire a depth-discrete sampling device that will allow sampling at least four axial wells during FY 1999. The proposed wells are TAN-40, TAN-38, PNA-4, and PNA-2. A key feature of the depth-discrete sampling device is the ability to repeatedly install and remove the system to support profiling of multiple wells over an extended period of time. Groundwater samples will be collected for volatile organic compounds (VOCs) (PCE, TCE, c-DCE, t-DCE, VC), tritium, indicator parameters (cations and anions), and water quality parameters (DO, ORP, SC, $\mathrm{pH}, \mathrm{T}$ ). Sampling for field measurement of dissolved gasses (ethene, ethane, methane, carbon dioxide, hydrogen) will be coordinated with EMSP research projects currently underway at TAN. The following tasks for FY 2000 and FY 2001 will include sampling the same wells sampled in FY 1999 and will add sampling of additional wells installed under Task 2 above:

Task 3.1-Acquire Depth-discrete Sampling Device

Task 3.2-FY 1999 Vertical Profile Sampling of TAN-40, 38, PNA-4, and PNA-2

- $\quad$ Activity 3.2a: Collect triplicate samples for VOCs, tritium, cations/anions, and water quality parameters 


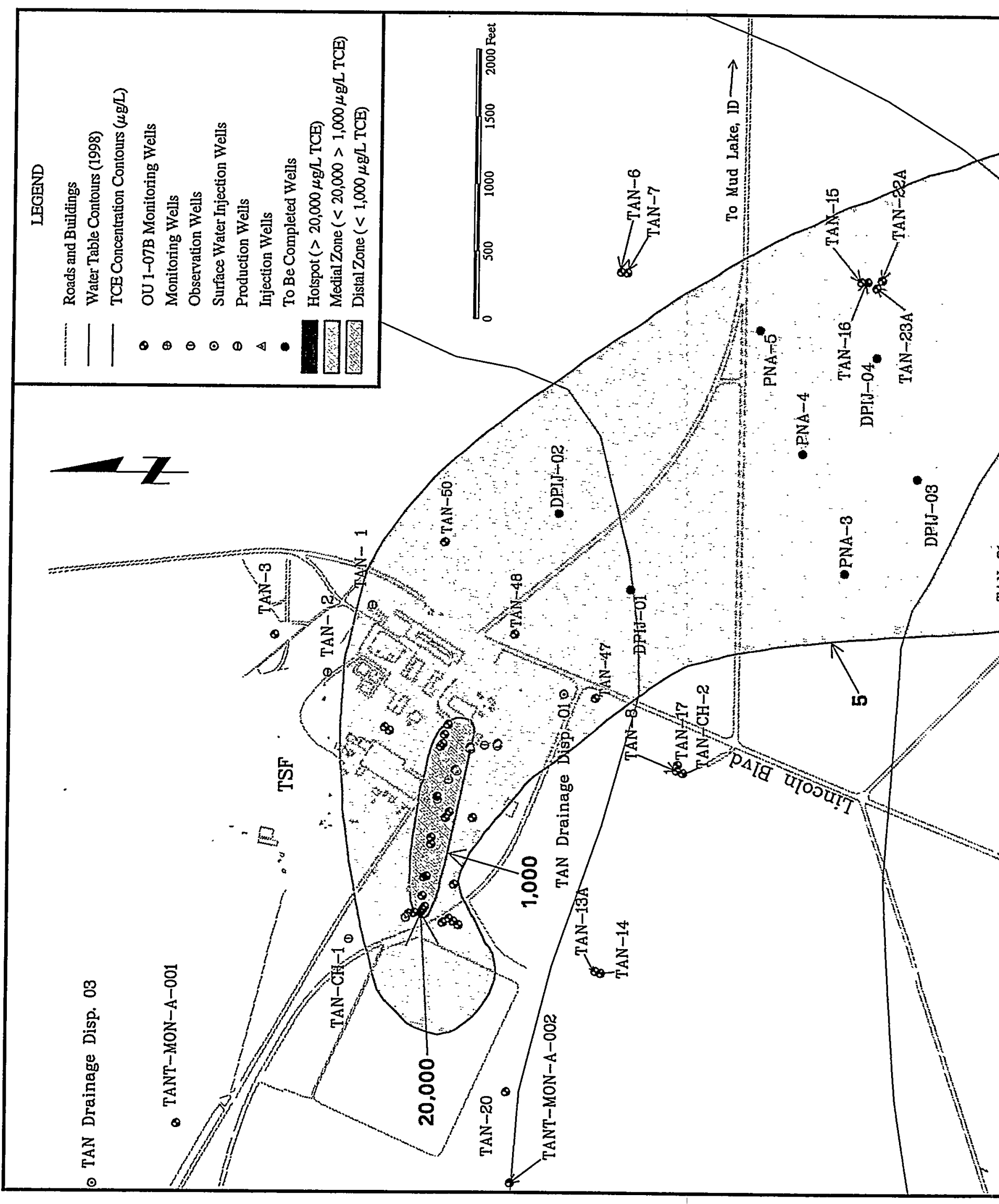




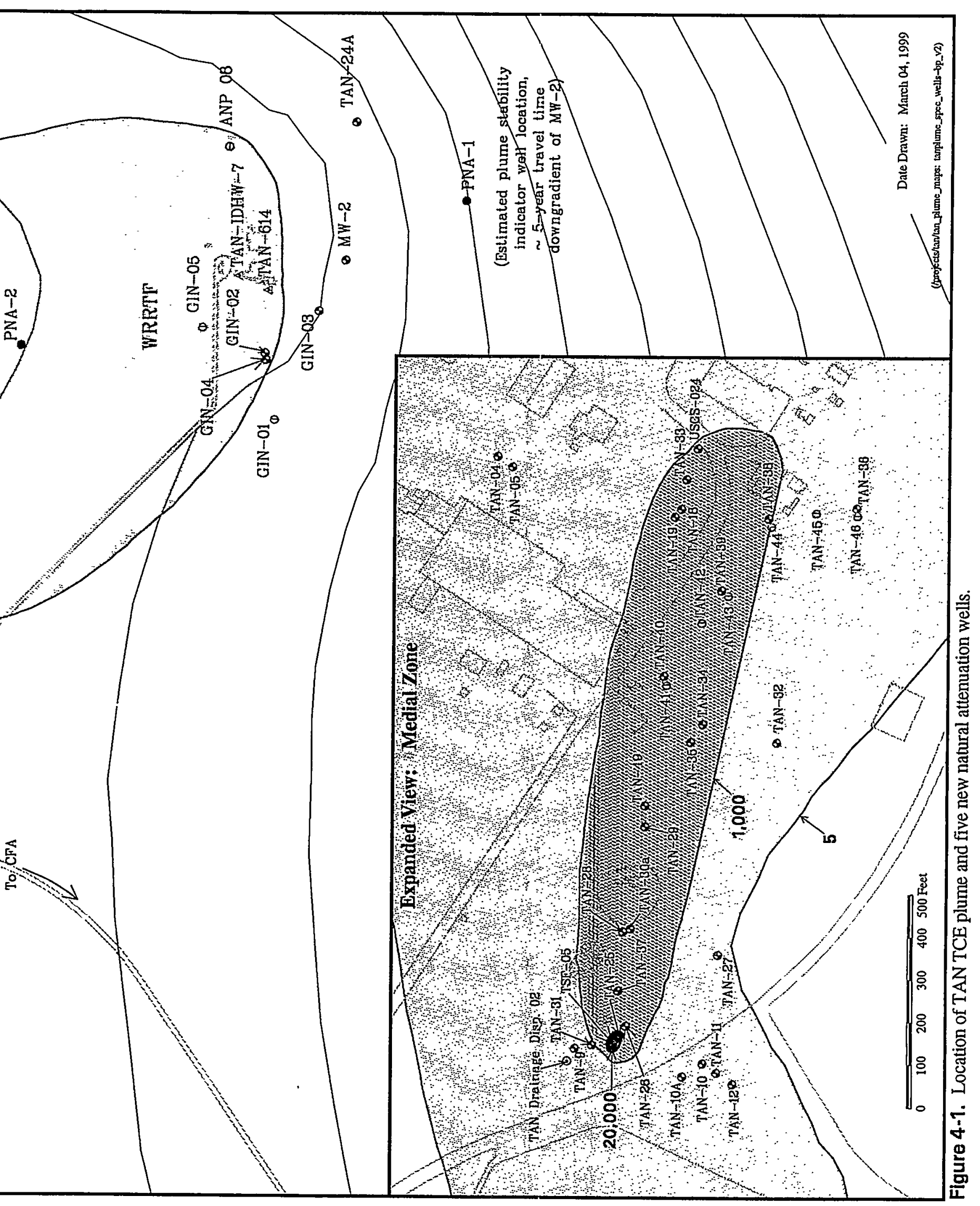




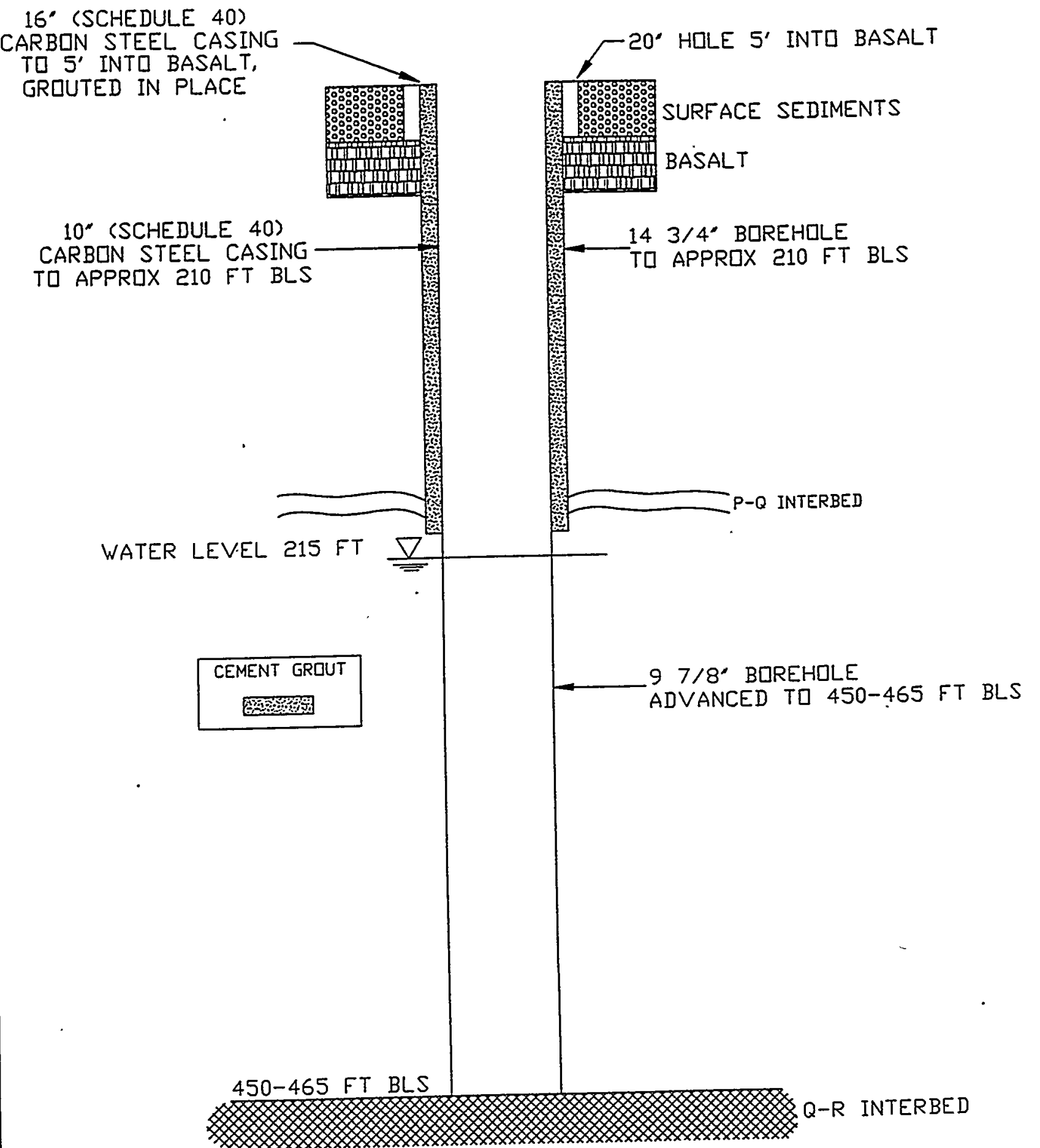

not to scale

Figure 4-2. Generalized completion log for new natural attenuation well. 
- Activity 3.2b: Analyze depth-discrete samples

- $\quad$ Activity 3.2c: FY 1999 data analysis and reporting

Task 3.3-FY 2000 Vertical Profile Sampling of TAN-40, 38, PNA-1, 2, 3, 4, and 5

- $\quad$ Activity 3.3a: Collect triplicate samples for VOCs, tritium, cations/anions, and water quality parameters

- $\quad$ Activity 3.3b: Analyze depth-discrete samples

- Activity 3.3c: FY 2000 data analysis and reporting

Task 3.4-FY 2001 Vertical Profile Sampling of PNA-1, 2, 3, 4, and 5

- $\quad$ Activity 3.4a: Collect triplicate samples for VOCs, tritium, cations/anions, and water quality parameters

- $\quad$ Activity 3.4b: Analyze depth-discrete samples

- Activity 3.4c: FY 2001 data analysis and reporting.

\subsubsection{Task 4: Technology Integration and Deployment Process Linkage}

The scope for Task 4 addresses the ASTD program guidance for leveraging implementing site (INEEL) knowledge to accelerate deployment to other participating sites. Key elements of this task are integrating the qualification, implementation, and deployment activities between participating sites. Specific activities include deployment integration, data analysis and site selection and qualification. Each of these elements consists of numerous activities as outlined below.

\section{Task 4.1-Deployment Integration}

The Deployment Integration task covers the management and coordination of activities necessary to insure maximum leverage of implementing site expertise. The integration activities focus on monitoring and reporting technical, regulatory/stakeholder, and business performance measures as outlined below and detailed in Project Tables presented in Appendix D. In addition the scope for this task will include a Deployment Technology Transfer activity which will cover presentation of enhanced ISB/MNA results at two or more national or international technical conferences or regulatory workshops. Presentation of site implementation and process validation data will be coordinated with the Remedial Technologies Development Forum (RTDF) and Western Governors' Association Interstate Technology Regulatory Cooperation (ITRC) protocols. The Task 4.1 activities include:

- Activity 4.1a: Technical Performance Monitoring:

- Validate that technical requirements have been incorporated into project strategy prior to Qualification and/or Implementation.

- Prepare and submit monthly technical performance reports.

- Coordinate implementation and deployment with the RTDF and ITRC. 
- Activity 4.1b: Regulatory and Stakeholder Involvement Monitoring:

- Identify regulatory participants and stakeholder organizations for each participating site

- Define a generalized approach to address regulatory and stakeholder concerns (Regulatory and Stakeholder Involvement Plan)

- Describe potential regulatory barriers to deployment of the proposed technology at the implementing site and subsequent deployment sites

- Coordinate regulatory input on specifications of technical requirements mandated by regulation

- Activity 4.1c: Business Performance Monitoring:

- Modify and maintain project baseline through control account and work package management.

- $\quad$ Prepare and submit monthly business performance reports (cost and schedule variance analysis).

- Implement corrective actions as necessary.

- Activity 4.1d Deployment Technology Transfer:

- Presentation of enhanced ISB/MNA results at one or more national or international technical conferences.

- Presentation of enhanced ISB/MNA results at one or more regulatory workshops.

- Coordinate implementation and deployment with the RTDF and ITRC.

\section{Task 4.2-Data Analysis}

Monitoring of enhanced ISB in the source area and monitoring of natural attenuation in the downgradient plume at TAN will generate the two primary data streams in this deployment. Significant data analysis will be required to evaluate the success of each primary component individually, as well as to evaluate the overall success of the integrated technology deployment. The scope for data analysis and integration includes the activities needed to evaluate the technical performance measures identified in Table 3-1. Seven specific measures were identified for enhanced ISB and seven for MNA. The measures are designed to evaluate incremental progress during the deployment toward the ultimate goal of accelerated site cleanup consistent with the ROD remedial action objectives. The microbial community monitoring (PLFA, SLB, and PCR) will be integrated into the evaluation of both technologies. In particular, geochemical data from ground water samples will be used with the results of the community monitoring to provide independent lines of evidence for degradation (or degradation potential). Finally, qualification of sites $B$ and $C$ will also require review of characterization data and discussion of those data with representatives from the sites. The scope also includes further review and/or data analysis required to evaluate the deployment at those sites. 


\section{Task 4.3-Site Selection and Qualification}

This scope will include a workshop for selection of two additional deployment sites. Of the four sites that have expressed interest in deploying enhanced ISB/MNA, two will be selected to participate in a phased deployment strategy. Through the site selection process, each site will be requested to review the INEEL implementing site documentation for enhanced ISB/MNA and participate in a workshop to be held at INEEL. Each site will present available information on their proposed remediation site as an element of site qualification. The selection and qualification activities are outlined below:

- Activity 4.3a: Site Selection:

- Conduct a Site Selection Workshop at INEEL to identify and prioritize two deployment sites.

- Identify characterization data gaps at sites B and C.

- $\quad$ Activity 4.3b: Site Qualification:

- $\quad$ Site B prepares Data Gap Characterization Plan.

- $\quad$ Conduct additional characterization at Site B to fill data gaps.

- $\quad$ Site C prepares Data Gap Characterization Plan.

- $\quad$ Conduct additional characterization at Site $\mathrm{C}$ to fill data gaps.

- Coordinate implementation and deployment with the RTDF and ITRC.

\subsubsection{Deployment at Sites B and C}

The ASTD funded scope for deployment of enhanced ISB/MNA is focused on the initial selection and prioritization of specific sites and OUs followed by qualification of the selected sites. Upon completion of the qualification step, participating site EM-40 organizations will fund and lead the on-site design, construction, and operation of the enhanced ISB/MNA system. ASTD involvement will be limited to providing implementing site field data, design, construction, and operations data, and accumulated staff expertise as requested by the participating sites.

\subsection{Schedule}

The implementation schedule for the enhanced ISB/MNA project and a comparison to the CERCLA baseline schedule is shown in Figure 4.3. A detailed logic diagram and Gantt chart identifying tasks, activities, deliverables, and milestones are presented in Appendix B. The basic elements of the ROD schedule and key milestones will not change during the time frame identified for technology deployment. The ASTD project implementation of monitored natural attenuation coupled with EM-40 implementation of enhanced ISB at the hot spot will provide deployment data necessary to meet the CERCLA Phase I and Phase II milestones (represented by stars in Figure 4.3). The Phase I decision will focus on the assessment of enhanced ISB relative to pump and treat remediation of the hot spot. The Phase II decision will include the assessment of monitored natural attenuation relative to dissolved phase pump and treat remediation of the downgradient portion of the plume. Coupling enhanced ISB with monitored natural attenuation will reduce the baseline pump and treat schedule for the hot spot by as 
much as $50 \%$, and monitored natural attenuation for the dissolved phase portion of the plume will reduce overall operating and maintenance cost even though it will likely be deployed over the entire restoration time frame.

Deployment of any technology at the INEEL TAN site or any other DOE site will necessarily have to consider the current status of the regulatory cleanup process. In the case of TAN, the CERCLA action has progressed through the assessment phase and is now in the RD/RA cleanup phase as defined in the OU 1-07B Record of Decision (DOE-ID 1995). The lower half of Figure 4.3 summarizes the CERCLA regulatory schedule currently in place for restoration of the TAN TCE plume. Primary enforceable milestones are represented by stars and are not subject to change. In terms of the ASTD deployment process, the significant CERCLA project milestones are completion of Phase I January 26, 2000 and Phase II by April 27, 2001. The upper half of Figure 4-3 provides the schedule logic for implementation of enhanced ISB/MNA TAN. The schedule shows that qualification has been completed by EM- 40 and that deployment can be completed within the ASTD goal of three years to meet and support the CERCLA milestone for technology evaluation and subsequent ROD amendment signifying formal deployment of the technology. Note that the ROD amendment process is not a component of the ASTD deployment project but is the responsibility of the CERCLA remedial project managers.

The important features of the proposed schedule are that ISB qualification is currently complete and was funded by EM-40; MNA deployment at TAN begins in FY-1999 and is co-funded through both the ASTD and EM-40 programs; deployment to other DOE sites begins in FY-2000, with an additional site deployment in subsequent years. The integration of ASTD and the TAN CERCLA remediation schedule depends on both programs recognizing the need for coordinated and timely implementation of scheduled activity. The INEEL deployment project team will have responsibility for both ASTD project tasks and TAN CERCLA tasks, hence this coordination will be easily accomplished by the project team.

\subsection{Budget}

Life-cycle project planning for enhanced ISB/MNA implementation and deployment has been organized along standard work breakdown structure tasks (work packages) with activity based networks for detailed implementation of each task. The cost estimate supporting the budget request has been prepared specifically for this deployment plan and has not appeared in a referenceable publication. The planning packages and logic diagrams have been prepared as a bottom up estimate to meet the requirements of project management and implementation at INEEL. The planning package approach will facilitate the rapid preparation of work packages required to begin scope of work upon ASTD approval of the deployment plan.

Table 4-1 summarizes the planning budget for deployment of enhanced ISB/MNA. The table is specifically designed to highlight ASTD and EM-40 matching funds budget by fiscal year and depoyment task. The total ASTD budget request is $\$ 1,500 \mathrm{~K}$ over the three-year project duration. The INEEL EM-40 program is supplying matching funds in the same amount. Sections 5 and 6 below present supporting cost data that demonstrate the significant leverage joint EM-50/EM-40 ownership and coordination can achieve.

\subsection{Reporting, Deliverables, and Milestones}

Monthly reports will be prepared following the recommended "Project Table" format to facilitate ASTD project management and performance monitoring of the enhanced ISB/MNA deployment project. Appendix $\mathrm{D}$ contains the detailed project tables that will be used to monitor progress of each of the four tasks defined in Section 4.1. The significant deliverables and milestones for each task are summarized in Table 4-2. 


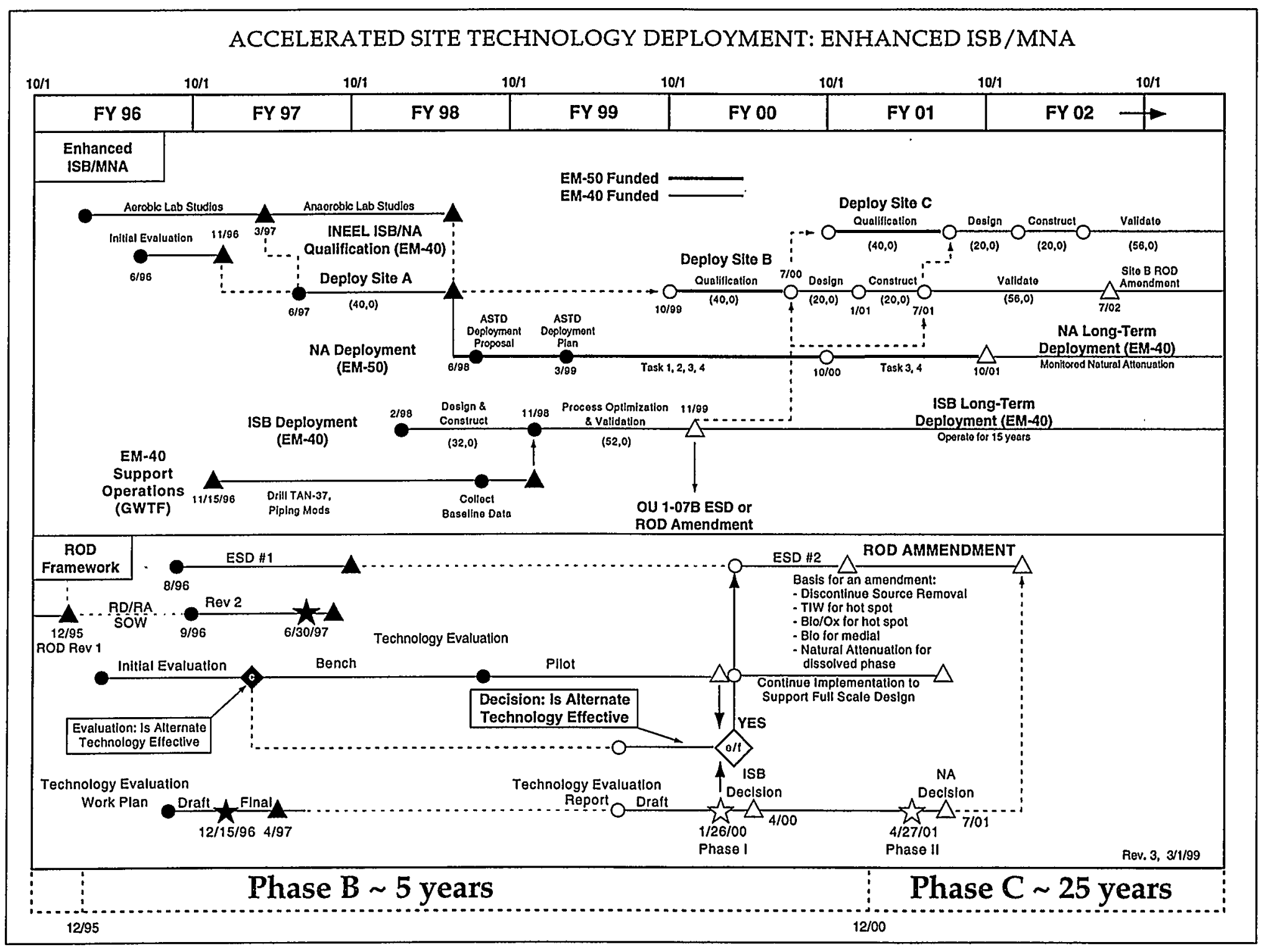

Figure 4-3. Implementation schedule for the enhanced ISB/MNA project and a comparison to the CERCLA baseline schedule. 
Table 4-1. Life-cycle cost estimate and generalized schedule for ASTD deployment of enhanced ISB/MNA

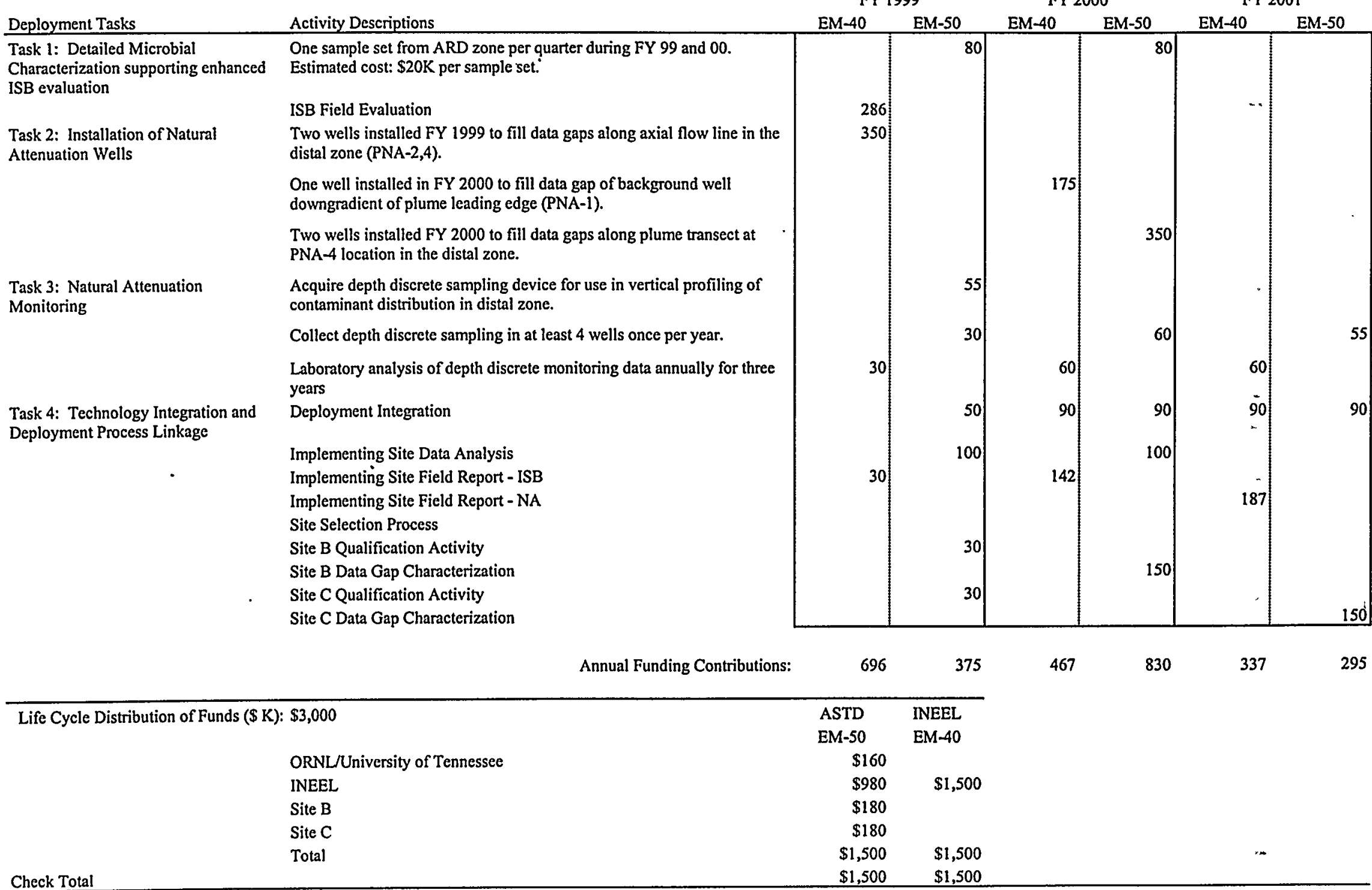


Table 4-2. Deliverables and milestones.

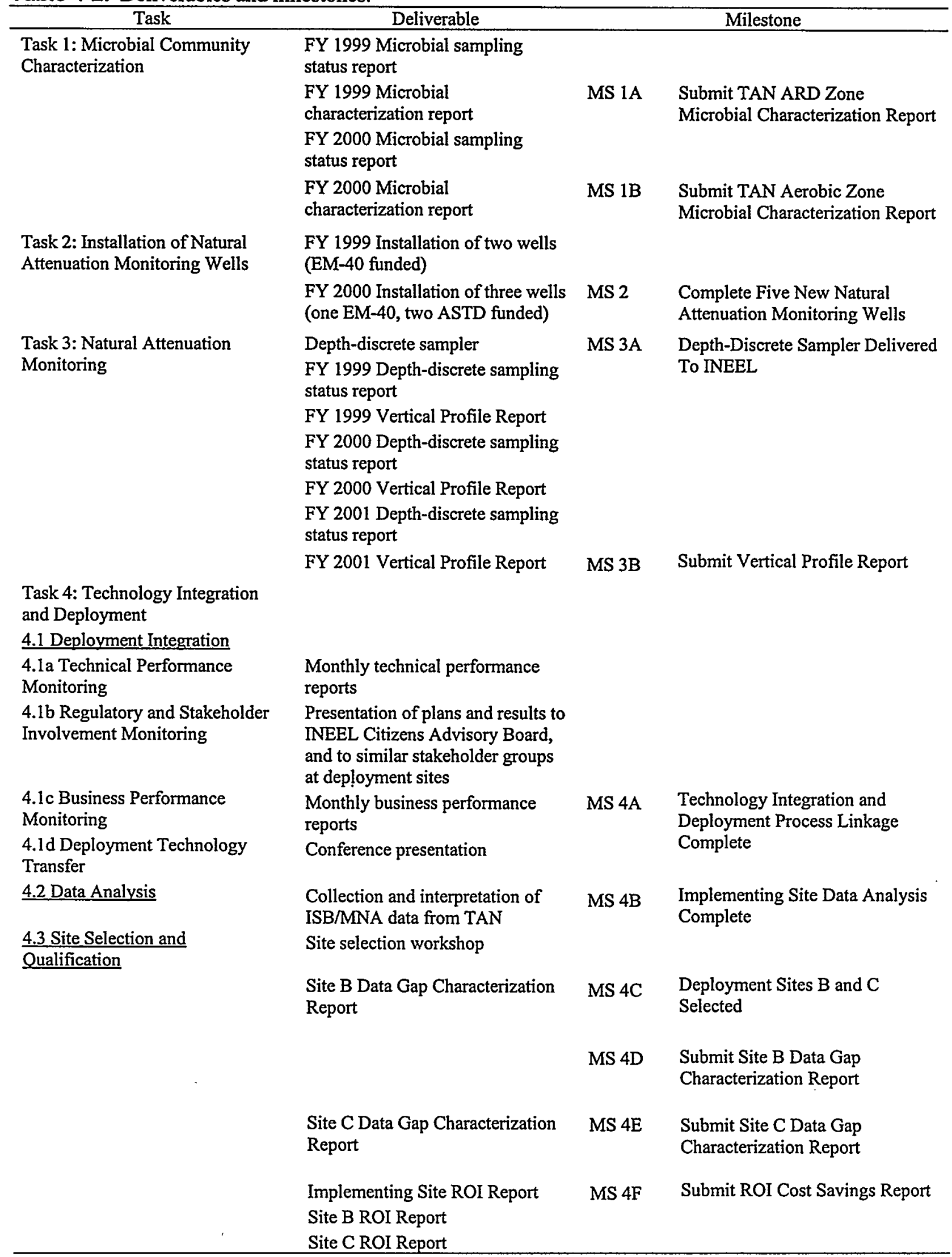




\section{COST BENEFIT ANALYSIS}

The estimated cost for implementing enhanced ISB/MNA at the three deployment sites is $\$ 51,516 \mathrm{~K}$, which represents an estimated savings of $\$ 73,481 \mathrm{~K}$ over the currently planned baseline pump and treat technology. (Additional details are presented in Section 6.) The ASTD contribution to the overall deployment cost is $\$ 1,500 \mathrm{~K}$ over 3 years, which results in a ROI factor of 50 for three DOE sites. Table 5-1 presents the estimated baseline cost summary for deployment of pump and treat at three sites. Table 5-2 presents the estimated costs for cleanup of the same three sites following deployment of combined enhanced ISB remediation of the secondary source area and MNA for the dissolved phase portion of the plume.

Table 5-1. Current baseline estimate for deployment of pump and treat at three sites.

\begin{tabular}{|c|c|c|c|c|c|c|c|}
\hline \multicolumn{5}{|c|}{ Project Cost Summary (Life Cost Estimates) (SK) } & \multicolumn{3}{|c|}{ Financial Costs (\$K) } \\
\hline \multirow[b]{2}{*}{$\begin{array}{c}\text { Activity Cost Element (Work Breakdown } \\
\text { Structure System Cost Components) }\end{array}$} & \multirow[b]{2}{*}{$\begin{array}{l}\text { Basis for } \\
\text { Estimate }\end{array}$} & \multirow[b]{2}{*}{$\begin{array}{l}\text { Base } \\
\text { Cost } \\
\end{array}$} & \multirow[b]{2}{*}{$\begin{array}{c}\text { Overhead } \\
\text { Burden } \\
\text { Allocation }\end{array}$} & \multirow[b]{2}{*}{$\begin{array}{c}\text { Life- } \\
\text { Cycle } \\
\text { Cost } \\
\text { Estimate }\end{array}$} & \multicolumn{2}{|c|}{ Support Costs } & \multirow{2}{*}{$\begin{array}{c}\text { Direct Costs } \\
\text { Operation } \\
\end{array}$} \\
\hline & & & & & $\begin{array}{l}\text { General } \\
\text { Support }\end{array}$ & $\begin{array}{l}\text { Mission } \\
\text { Support } \\
\end{array}$ & \\
\hline $\begin{array}{l}1.0 \text { Initial Activities } \\
\text { (Characterization, Design, Assessment) }\end{array}$ & - & 2,098 & 987 & 3,085 & . & $\therefore$ & \\
\hline 2.0 Mobilization Costs & - & 150 & 70 & 220 & ${ }^{\circ}$ & & - \\
\hline $\begin{array}{l}\text { 3.0 Production Facility Costs } \\
\text { 3.1 Setup } \\
\text { 3.2 Treatment } \\
\text { 3.3 Demobilization }\end{array}$ & - & 16,309 & 2,294 & 18,683 & & & $\therefore$ \\
\hline $\begin{array}{l}\text { 4.0 ES\&H and Assurance } \\
4.1 \text { Safety Assurance } \\
4.2 \text { Permitting } \\
4.3 \text { Project Management }\end{array}$ & - & 16,114 & 7,583 & 23,697 &  & & $\begin{array}{c}\cdot \\
\vdots \\
\vdots \\
\end{array}$ \\
\hline 5.0 Operating and Maintenance Costs & - & 52,671 & 24,787 & 77,058 & . & & $\therefore$ \\
\hline 6.0 Decontamination and Decommissioning & 二 & 1,261 & 593 & 1,854 & & & \\
\hline Total Life-Cycle Costs & - & 88,683 & 36,314 & 124,997 & 16,850 & 22,171 & 49,662 \\
\hline
\end{tabular}


Table 5-2. ASTD cost estimate for deployment of ISB/MNA at three sites.

\begin{tabular}{|c|c|c|c|c|c|c|c|c|}
\hline \multicolumn{5}{|c|}{ Project Cost Summary (Life Cost Estimates) (SK) } & \multicolumn{4}{|c|}{ Financial Costs $(S K)$} \\
\hline \multirow[b]{2}{*}{$\begin{array}{l}\text { Activity Cost Element (Work Breakdown } \\
\text { Structure System Cost Components) }\end{array}$} & \multirow[b]{2}{*}{$\begin{array}{l}\text { Basis for } \\
\text { Estimate }\end{array}$} & \multirow[b]{2}{*}{$\begin{array}{l}\text { Base } \\
\text { Cost }\end{array}$} & \multirow[b]{2}{*}{$\begin{array}{c}\text { Overhead } \\
\text { Burden } \\
\text { Allocation }\end{array}$} & \multirow[b]{2}{*}{$\begin{array}{c}\text { Life-Cycle } \\
\text { Cost } \\
\text { Estimate }\end{array}$} & \multicolumn{2}{|c|}{ Support Costs } & \multirow{2}{*}{$\begin{array}{c}\begin{array}{c}\text { Direct } \\
\text { Costs }\end{array} \\
\text { Operation }\end{array}$} & \multirow[b]{2}{*}{ Leverage } \\
\hline & & & & & $\begin{array}{l}\text { General } \\
\text { Support }\end{array}$ & $\begin{array}{l}\text { Mission } \\
\text { Support }\end{array}$ & & \\
\hline $\begin{array}{l}1.0 \text { Initial Activities } \\
\text { (Characterization, Design, Assessment) }\end{array}$ & - & 863 & 408 & 1,271 & $\therefore \because \because$ & $\because \because \cdots$ & $\because$ & 37 \\
\hline 2.0 Mobilization Costs & - & 64 & 27 & 91 & $\therefore \therefore$ & $\because \because$ & $\therefore$ & 3 \\
\hline $\begin{array}{l}\text { 3.0 Production Facility Costs } \\
\text { 3.1 Setup } \\
\text { 3.2 Treatment } \\
\text { 3.3 Demobilization }\end{array}$ & Sec. 4.2 & 6,754 & 946 & 7,700 & & & $\begin{array}{l}\cdots \\
\because \\
\because\end{array}$ & 224 \\
\hline $\begin{array}{l}\text { 4.0 ES\&H and Assurance } \\
\text { 4.1 Safety Assurance } \\
4.2 \text { Permitting } \\
\text { 4.3 Project Management }\end{array}$ & Sec. 4.2 & 6,641 & 3,125 & 9,766 & & $\begin{array}{l}\therefore \\
\therefore \vdots \\
\therefore \therefore \\
\therefore\end{array}$ & $\begin{array}{r}\ddots \\
\ddots \\
\ddots \\
\ddots\end{array}$ & 284 \\
\hline 5.0 Operating and Maintenance Costs & Sec. 4.2 & 21,708 & 10,215 & 31,923 & $\because \therefore \because$ & & $\because \because \because$ & 952 \\
\hline 6.0 Decontamination and Decommissioning & - & 535 & 229 & 764 & $\because$ & $\therefore \therefore:$ & $\because$ & - \\
\hline Total Life-Cycle Costs & - & 36,566 & 14,950 & 51,516 & 6,946 & 9,141 & 20,479 & 1,500 \\
\hline
\end{tabular}




\section{RETURN ON INVESTMENT}

A primary objective of the ASTD program is to effect cost savings and/or schedule acceleration for the DOE cleanup effort. 'Each participating site will calculate return on investment (ROI) and provide the calculation and supporting information for third party validation. The validated cost savings will be available for use at the participating sites. Table 6-1 presents the ROI analysis for deployment at TAN and for three sites. The cost benefit of multiple site deployment is readily apparent. Details of the supporting cost information and the ROI analysis were presented in the enhanced ISB/MNA proposal (INEEL 1998 [LD-98-187]).

The strategy for determination of the ROI presented in Table 6-1 is based on comparison of two cost estimates. The first estimate is the actual baseline remediation life cycle cost taken from the implementing site ROD and subsequent RD/RA SOW. The second component is an estimate arrived at by subtracting annual line item costs not required as a component of the enhanced ISB/MNA technology from the baseline life cycle estimate. The details of this calculation were presented in the original proposal (INEEL 1998). Following this strategy, the estimated cost savings for the implementing site would be $\$ 13,993 \mathrm{~K}$ for an ASTD ROI of 9.33. Detailed baseline estimates for other participating sites are not available so the ROI for implementation of enhanced ISB/MNA at three sites is calculated assuming one site will be one third less costly than the implementing site, and another site will be one third more costly.

The ROI resulting from concurrent deployment of enhanced ISB/MNA is based on several key components captured in Tables 5-1 and 5-2. The components of the baseline technology that drive cost estimates are facility construction and long-term operations and maintenance $(56 \%)$ and the associated long-term administrative project management costs (17\%). In contrast, implementation of NA of the dissolved phase will reduce long term operations and maintenance costs associated with the dissolved phase pump and treat units and ISB at the hot spot is estimated to have a $50 \%$ shorter life cycle relative to the baseline pump and treat operation. Operations and maintenance staffing costs for both NA and ISB are lower by a similar amount because the NA component requires only annual monitoring and the ISB facility infrastructure is simple pumps, piping, and nutrient mixing equipment.

The implementing and participating deployment sites will prepare a ROI report that presents the calculations and supporting information to:

- $\quad$ Estimate cost savings against the baseline

- Describe proposed re-investment of savings into TYP activities

- Estimate additional cost savings and schedule acceleration resulting from reinvestment.

Table 6-1. Return on investment (dollars in thousands).

\begin{tabular}{lcc}
\hline & TAN & Deployment at Three Sites \\
\hline A. Original EM Baseline Costs & 48,303 & 124,997 \\
B. Proposed Costs for Project & 34,310 & 51,516 \\
Cost Savings & 13,993 & 73,481 \\
C. ASTD Portion of Proposed Deployment & 1,500 & 1,500 \\
$\quad$ Costs (FY-99/00 total) & & 48.99 \\
Return on Investment & 9.33 & \\
\hline
\end{tabular}




\section{REFERENCES}

Air Force Center for Environmental Excellence, 1995, Technical Protocol for Implementing Intrinsic Remediation with Long-term Monitoring for Natural Attenuation of Fuel Contamination Dissolved in Groundwater, Brooks Air Force Base, San Antonio, Texas, June.

Air Force Center for Environmental Excellence, 1996, Technical Protocol for Evaluating Natural Attenuation of Chlorinated Solvents in Groundwater (Draft), Brooks Air Force Base, San Antonio, Texas, November.

Alleman, B.C. and A. Leeson, eds., 1997, Fourth International In Situ and On-site Bioremediation Symposium, Battelle Press, Columbus, OH, 1997.

California Senate Bill 1764 Advisory Committee, 1996, "Recommendation Report to the State Water Resources Control Board", May.

DOE, 1998, Ten-year Plan, Accelerating Cleanup: Paths to Closure, DOE/EM-0342, June.

DOE-ID, 1995, Record of Decision: Declaration for the Technical Support Facility Injection Well (TSF05) and Surrounding Groundwater Contamination (TSF-23) and Miscellaneous No Action Sites Final Remedial Action, Operable Unit 1-07B, Waste Area Group 1, Idaho Falls, Idaho, Idaho National Engineering and Environmental Laboratory, U.S. Department of Energy, U.S. Environmental Protection Agency, Division of Environmental Quality, Idaho Department of Health and Welfare, August.

DOE-ID, 1997, Technology Evaluation Work Plan, Test Area North Final Groundwater Remediation Operable Unit 1-07B, U.S. Department of Energy Idaho Operations Office, DOE/ID-10562.

DOE-ID, 1998a, In Situ Bioremediation Field Evaluation Infrastructure Final Design Test Area North Operable Unit 1-07B, U.S. Department of Energy Idaho Operations Office, DOE/ID-10645.

DOE-ID, 1998b, In Situ Bioremediation Field Evaluation Alternate Design Test Area North, Operable Unit 1-07B, U.S. Department of Energy Idaho Operations Office, DOE/ID-10628.

EPA, 1997, Use of Monitored Natural Attenuation at Superfund, RCRA Corrective Action, and Underground Storage Tank Sites, Directive 9200.4-17, Office of Solid Waste and Emergency Response, November.

EPA, 1998, Technical Protocol for Evaluating Natural Attenuation of Chlorinated Solvents in Groundwater, EPA/600/R-98-128, September.

Hinchee, R. E., ed., Proceedings, 1991 International Bioreclamation Symposium, Battelle Press, Columbus, OH, 1991.

Hinchee, R. E., ed., Proceedings, 1993 International Bioreclamation Symposium, Battelle Press, Columbus, OH, 1993.

Hinchee, R. E., ed., Proceedings, 1995 International Bioreclamation Symposium, Battelle Press, Columbus, OH, 1995. 
INEEL, 1998, Bioremediation and Natural Attenuation for In Situ Restoration of ChloroetheneContaminated Groundwater. Proposal submitted to the Accelerated site Technology Deployment Program, Idaho National Engineering and Environmental Laboratory, June (LD-98-187).

LMITCO, 1998a, Microbial Studies Report Supporting Implementation of In Situ Bioremediation at Test Area North, Lockheed Martin Idaho Technologies Company, INEEL/EXT-98-00474.

LMITCO, 1998b, Development of a Numerical Model with Physically-Based Vertical Discretization to Support the In Situ Bioremediation Field Evaluation at Test Area North, Lockheed Martin Idaho Technologies Company, INEEL/EXT-90-00418.

LMITCO, 1998c, In Situ Bioremediation Modeling Report for Test Area North final Groundwater Remediation Operable Unit 1-07B, Lockheed Martin Idaho Technologies Company, INEEL/EXT98-00418.

LMITCO, 1998d, Sampling and Analysis Plan for the Enhanced In Situ bioremediation Field Evaluation Test Area North, Operable Unit 1-07B, Lockheed Martin Idaho Technologies Company, INEEL/EXT-98-00421. 


\section{APPENDIX A}

\section{Authorization Letter From ASTD Program}




\title{
Department of Energy \\ Idaho Operations Office \\ 850 Energy Drive- \\ Idaho Falls, tdaho 83401-1563
}

December 11, 1998

\author{
Ms. Kathleen E. Hain \\ Director \\ Environmental Restoration \\ U.S. Department of Energy \\ Idaho Operations Office \\ 785 DOE Place \\ MS 1118-ID South \\ Idaho Falls, Idaho 83401
}

SUBJECT: 99 ASTD 41-Bioremediation and Natural Attenuation for In-Situ Restoration of Chloroethene-Contaminated Groundwater (LD-98-464)

Dear Ms. Hain:

The above referenced proposal submitted to the Accelerated Site Technology Deployment Program has been approved for funding. The notice youreceived in late November from Gerald. Boyd, the Acting Deputy Assistant Secretary of the Office of Science and Technology, describes FY99 budget constraints affecting the ASTD Program.

That notice also addressed a separate funding allocation for the purpose of formulating revisions to your Deployment Plan. That allocation will-be 25\% of the proposed FY99-budget allocation for your project or fifty thousand dollars, whichever is less. This supplemental funding will be provided in the January Financial. Plan to cover the cost of revisions to bring the Deployment Plan into agreement with the project's new funding profile. The revised Deployment Plan or addendum-and-a-short-form ITP, should-be submitted electronically, and by hard copy no later than COB January 30, 1999 to:

George Schneider

ASTD Field Program Manager

U.S. Department of Energy-

850 Energy Drive

Idaho Falls, Idaho, 83401

e-mail: schneigj@inel.gov 
Please also send electronic and hard copies directly to:

\section{Kurt Gerdes}

ASTD Headquarter Program Manager

U.S. Department of Energy

Cloverleaf Building, EM-53

19901 Germantown Road,

Germantown, Maryland 20874-1290

e-mail: Kurt Gerdes@em.doe.gov

The revised Deployment Plan or addendum should include a schedule for the project that meets the new funding profile provided in your December.11, 1998-submittal to EM Headquarters. Please ensure that the revised proposal clearly identifies all non EM-50 funding, both amount and source of funds, to be used in this proposed project.

Questions pertaining to this request should be addressed to George Schneider (208-526-6789). Information on the program and-the program's requirements-for deployment plans are-available on the ASTD web site at http://infoshare.inel.gov/astd/. The web site is also linked to the INEEL home page. Your prompt response to-this-request for information will help us insure that initial funding can be available as soon as possible.

Sincerely,

George J. Schneider, ASTD Program Manager, DOE-ID

cc: Jef Walker, DOE-HQ, EM-50.

Kurt Gerdes, DOE-HQ, EM-50 


\section{APPENDIX B}

Cost Estimate Spreadsheets 
The current EM-40 baseline for the Test Area North Groundwater Restoration project includes matching funds to demonstrate joint ownership and coordination with the EM-50 deployment of enhanced in situ bioremediation and monitored natural attenuation. The list below summarizes specific line item matching funds that support implementation of enhanced ISB/MNA for deployment at INEEL. The activity number refers to line item activities as they appear on the attached Cost Estimate Summary Sheets. Note that a portion of the matching funds are identified as "To Be Included" in future baseline change proposals.

Table B-1. EM-40 matching funds summary.

\begin{tabular}{|c|c|c|}
\hline Activity & Title & Amount ( $\$$ in thousands) \\
\hline $11-0060$ & Prepare Phase I FDR & $\$ 130.1$ \\
\hline $11-0065$ & $\begin{array}{l}\text { Draft FDR Phase I Comment } \\
\text { Resolution and Incorporation }\end{array}$ & $\$ 24.8$ \\
\hline $11-0070$ & $\begin{array}{l}\text { Draft Final FDR Phase I } \\
\text { Comment Resolution and } \\
\text { Incorporation }\end{array}$ & $\$ 16.7$ \\
\hline $11-1027$ & $\begin{array}{l}\text { Drill Bioremediation Monitoring } \\
\text { Well }\end{array}$ & $\$ 181.6$ \\
\hline $11-1005-3$ & Tracer Test & $\$ 87.4$ \\
\hline $11-0055$ & $\begin{array}{l}\text { Replanning for FY } 99 \text { Based on } \\
\text { Funding Constraints }\end{array}$ & $\$ 17.2$ \\
\hline $11-2570$ & Prepare Phase II FDR & $\$ 127.7$ \\
\hline $11-2575$ & $\begin{array}{l}\text { Draft FDR Phase II Comment } \\
\text { Resolution and Incorporation }\end{array}$ & $\$ 40.3$ \\
\hline $11-2580$ & $\begin{array}{l}\text { Draft Final FDR Phase II } \\
\text { Comment Resolution and } \\
\text { Incorporation }\end{array}$ & $\$ 22.8$ \\
\hline $11-3070$ & $\begin{array}{l}\text { Drill Natural Attenuation } \\
\text { Monitoring Well PNA-4 }\end{array}$ & $\$ 135.5$ \\
\hline TBI & Containment Pad for PNA-4 & $\$ 39.5$ \\
\hline $11-3072$ & $\begin{array}{l}\text { Drill Natural Attenuation } \\
\text { Monitoring Well PNA-2 }\end{array}$ & $\$ 135.5$ \\
\hline TBI & Containment Pad for PNA-2 & $\$ 39.5$ \\
\hline $11-3074$ & $\begin{array}{l}\text { Drill Natural Attenuation } \\
\text { Monitoring Well PNA-1 }\end{array}$ & $\$ 135.5$ \\
\hline TBI & Containment Pad for PNA-1 & $\$ 39.5$ \\
\hline TBI & $\begin{array}{l}\text { FY } 1999 \text { Laboratory Analysis, } \\
\text { Depth-discrete samples }\end{array}$ & $\$ 30.0$ \\
\hline TBI & $\begin{array}{l}\text { FY } 2000 \text { Laboratory Analysis, } \\
\text { Depth-discrete samples }\end{array}$ & $\$ 60.0$ \\
\hline TBI & $\begin{array}{l}\text { FY } 2001 \text { Laboratory Analysis, } \\
\text { Depth-discrete samples }\end{array}$ & $\$ 60.0$ \\
\hline TBI & FY 2000 Deployment Integration & $\$ 90.0$ \\
\hline TBI & FY 2000 Deployment Integration & $\$ 90.0$ \\
\hline
\end{tabular}


L $: O$

ENVIRONMENTAL RESTORATION (ER)

WORK PACKAGE COVER SHEET

Work Package Title:

\section{Start Date:}

ility Study

WP-11 Pha
01-OCT-98

17-SEP-98

Work Package No:

LANCE N PETERSON

$3 \times N C C 4 B 00$

03-DEC-01

C.1.01.01.02.19.BB

\begin{tabular}{|l}
\hline Effective: \\
\hline Work Package Manager: \\
\hline
\end{tabular}

CWBS Element No:

BCWS IN DOLLARS

\begin{tabular}{|c|c|c|c|c|c|c|c|c|c|c|c|c|}
\hline Description & $\begin{array}{l}\text { Prior } \\
\text { Years }\end{array}$ & FY 94 & FY 95 & FY 96 & FY 97 & FY 98 & FY 99 & FY OO & FY 01 & FY 02 & FY 03 & FY 04 \\
\hline 1. Baseline & $\$ 0$ & $\$ 0$ & $\$ 0$ & $\$ 0$ & $\$ 0$ & $\$ 0$ & $\$ 0$ & $\$ 0$ & $\$ 0$ & $\$ 0$ & $\$ 0$ & $\$ 0$ \\
\hline 2. Change & $\$ 0$ & $\$ 0$ & $\$ 0$ & $\$ 0$ & $\$ 0$ & $\$ 0$ & $\$ 2095639$ & $\$ 2066046$ & $\$ 915460$ & $\$ 36846$ & $\$ 0$ & $\$ 0$ \\
\hline 3. Revised Total & $\$ 0$ & $\$ 0$ & $\$ 0$ & $\$ 0$ & $\$ 0$ & $\$ 0$ & $\$ 2095639$ & $\$ 2066046$ & $\$ 915460$ & $\$ 36846$ & $\$ 0$ & $\$ 0$ \\
\hline
\end{tabular}

\begin{tabular}{|c|c|c|c|c|c|c|c|c|c|c|c|c|}
\hline Description & FY 05 & FY 06 & FY 07 & FY 08 & FY 09 & FY 10 & FY 11 & FY 12 & FY 13 & FY 14 & FY 15 & FY 16 \\
\hline 1. Baseline & $\$ \$$ & $\$ 0$ & $\$ 0$ & $\$ 0$ & $\$ 0$ & $\$ 0$ & $\$ 0$ & $\$ 0$ & $\$ 0$ & $\$ 0$ & $\$ 0$ & $\$ 0$ \\
\hline 2. Change & $\$ 0$ & $\$ 0$ & $\$ 0$ & $\$ 0$ & $\$ 0$ & $\$ 0$ & $\$ 0$ & $\$ 0$ & $\$ 0$ & $\$ 0$ & $\$ 0$ & $\$ 0$ \\
\hline 3. Revised Total & $\$ 0$ & $\$ 0$ & $\$ 0$ & $\$ 0$ & $\$ 0$ & $\$ 0$ & $\$ 0$ & $\$ 0$ & $\$ 0$ & $\$ 0$ & $\$ 0$ & $\$ 0$ \\
\hline
\end{tabular}

\begin{tabular}{|c|c|c|c|c|c|c|c|c|c|c|c|c|}
\hline Description & FY 17 & FY 18 & FY 19 & FY 20 & FY 21 & FY 22 & FY 23 & FY 24 & FY 25 & FY 26 & $\begin{array}{c}\text { Subsequent } \\
\text { Years }\end{array}$ & TOTAL \\
\hline 1. Baseline & $\$ 0$ & $\$ 0$ & $\$ 0$ & $\$ 0$ & $\overline{\$ \$ 0}$ & $\overline{\$ \$ 0}$ & $\$ 0$ & $\$ 0$ & $\$ 0$ & $\$ 0$ & $\$ 0$ & $\$ 0$ \\
\hline 2. Change & $\$ 0$ & $\$ 0$ & $\$ 0$ & $\$ 0$ & $\$ 0$ & $\$ 0$ & $\$ 0$ & $\$ 0$ & $\$ 0$ & $\$ 0$ & $\$ 0$ & $\$ 5113991$ \\
\hline 3. Revised Total & $\$ 0$ & $\$ 0$ & $\$ 0$ & $\$ 0$ & $\$ 0$ & $\$ 0$ & $\$ 0$ & $\$ 0$ & $\$ 0$ & $\$ 0$ & $\$ 0$ & $\$ 5113991$ \\
\hline
\end{tabular}

\begin{tabular}{|c|c|c|c|c|c|c|c|c|}
\hline $\begin{array}{l}\text { Revision } \\
\text { Number }\end{array}$ & BCP Ref. \# & $\begin{array}{c}\text { Revision } \\
\text { Date }\end{array}$ & $\begin{array}{l}\text { Revision } \\
\text { Number }\end{array}$ & BCP Ref. \# & $\begin{array}{c}\text { Revision } \\
\text { Date }\end{array}$ & $\begin{array}{l}\text { Revision } \\
\text { Number }\end{array}$ & BCP Ref. \# & $\begin{array}{c}\text { Revision } \\
\text { Date }\end{array}$ \\
\hline- & $98-133$ & 17-SEP-98 & & & & & & \\
\hline & & & & & & & & \\
\hline & & & & & & & & \\
\hline & & & & & & & & \\
\hline
\end{tabular}

Control Account Manager 


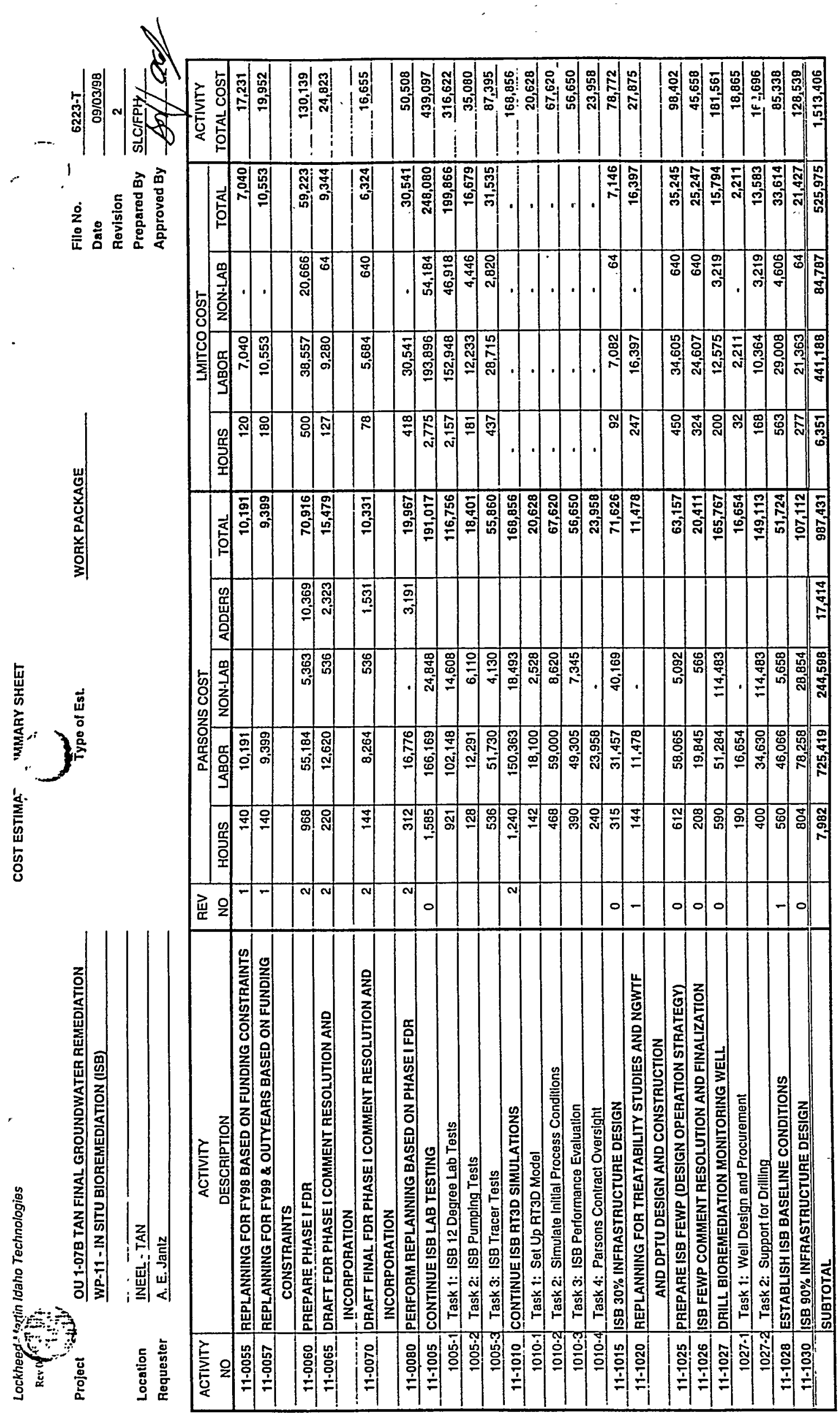




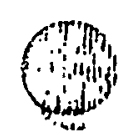

Lockhoed Martin Idaho Technologies

Rev (12.95

Page

2 of 2
COST ESTIMATE SUMMARY SHEET

Type of Est.
Workerlanning Package
File No.

Date

Revision $\frac{6223 . T}{09103 / 98}$ 09/03/98 WP.11 - IN SITU CHEMICAL OXIDATION

\begin{tabular}{|c|c|c|c|c|c|c|c|c|c|c|c|c|}
\hline \multirow{2}{*}{$\begin{array}{c}\text { ACTIVITY } \\
\text { NO }\end{array}$} & \multirow{2}{*}{$\begin{array}{l}\text { ACTIVITY } \\
\text { DESCRIPTION }\end{array}$} & \multirow{2}{*}{$\begin{array}{l}\text { REV } \\
\text { NO }\end{array}$} & \multicolumn{5}{|c|}{ PARSONS COST } & \multicolumn{4}{|c|}{ LMITCO COST } & \multirow[t]{2}{*}{ ACTIVITY } \\
\hline & & & HOURS & LABOR & NON-LAB & ADDERS & TOTAL & HOUAS & LABOR & NON-LAB & TOTAL & \\
\hline $11-2550$ & HOT SPOT ISCO FIELD EVALUATION OPTIMIZATION PHASE & 2 & 1,680 & 95,400 & 67,482 & 21,179 & 184,061 & 1,994 & 117.300 & 119,942 & 237,242 & 421,303 \\
\hline $2550 \cdot 1$ & Task 1: Optimization & & 1,680 & 95,400 & 67,482 & 21,179 & 184.061 & 336 & 20,143 & 33,504 & 53,647 & 237.708 \\
\hline $2550 \cdot 2$ & Task 2: Oplimizalion Process Moniloring & & - & - & - & - & - & 1,658 & 97.157 & 86,438 & 183,595 & 183,595 \\
\hline $11-2555$ & HOT SPOT ISCO FIELD EVALUATION VALIDATION PHASE & 2 & 1,677 & 95,187 & 71,396 & 21,359 & 187,942 & 1,902 & 121,215 & 58,252 & 179,467 & 367,409 \\
\hline $2555-1$ & Task 1: Validation & & 1,677 & 95,187 & 71,396 & 21,359 & 187,942 & 739 & 52,753 & 128 & 52,881 & 240,823 \\
\hline $2555-2$ & Task 2: Valldation Process Moniloring & & - & - & - & - & - & 1.163 & 68,462 & 58,124 & 126,586 & $126,586$. \\
\hline \multirow[t]{2}{*}{11.2560} & PREPARATION OF HOT SPOT ISCO FIELD EVALUATION & 2 & 880 & 50,640 & 2,681 & 9,333 & 62,654 & 492 & 33,977 & 640 & 34,617 & 97,271 \\
\hline & REPORT & & & & & & & & & & & \\
\hline $11-2565$ & ISCO TECHNICAL INTEGRATION ACTIVITIES FY-00 (1rSt Hali) & 2 & 96 & 4,608 & - & 951 & 5,559 & 1,152 & 90,644 & 10.212 & 100,856 & 106,415 \\
\hline $11-2567$ & ISCO TECHNICAL INTEGRATION ACTIVITIES FY-OO (2nd Half) & $\underline{2}$ & 96 & 4,608 & - & 951 & 5,559 & 1,392 & 111,485 & 10,212 & 121,697 & 127,256 \\
\hline $11-2570$ & PAEPARE PHASE IFDR & 2 & 1,080 & 62,360 & 5,363 & 11.579 & 79,302 & 668 & 47,097 & 1,280 & 48,377 & 127,679 \\
\hline \multirow[t]{2}{*}{$11-2575$} & DRAFT FDR PHASE \| COMMENT RESOLUTION AND & 2 & 344 & 19,784 & 1,073 & 3,649 & 24,505 & 206 & 14,478 & 1,280 & 15,758 & 40,264 \\
\hline & INCORPORATION & & & & & & & & & & & \\
\hline \multirow[t]{2}{*}{$11-2580$} & DRAFT FINAL FDA PHASE $\|$ COMMENT RESOLUTION AND & 2 & 244 & 14,294 & 536 & 2,590 & 17,420 & 59 & 4,136 & 1.280 & 5,416 & $22,836$. \\
\hline & INCORPORATION & & & & & & & & & & & \\
\hline $11-2585$ & IREATABILITY STUDY TECHNICAL INTEGRATION FY-01 & 2 & 528 & 25,344 & & 5,234 & 30,578 & 4.039 & 318,615 & 10,212 & 328,827 & 359,405 \\
\hline $11-2590$ & PERFORM REPLANNING BASED ON FDR PHASE $\|$ & 2 & 416 & 22,368 & - & 4,255 & 26,623 & 558 & 35,993 & $\therefore$ & 35,993 & 62,616 \\
\hline & & & & & 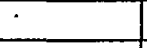 & & & & & & & \\
\hline & & & & & & & & & & & & \\
\hline & & & & & & & & & & & & \\
\hline & & & & & & & & & & & & \\
\hline & & & & & & & & & & & & \\
\hline & & & & & & & & & & & & \\
\hline & TOTAL WP-1I - IN SITU CHEMICAL OXIDATION (ISCO) & & 11,767 & 759,100 & 352,791 & 114,198 & $1,226,089$ & 18,197 & $1,304,402$ & 571,058 & $1,675,460$ & $3,101,549$ \\
\hline
\end{tabular}


Location INEL - TAN

Requester A. E. Jantz

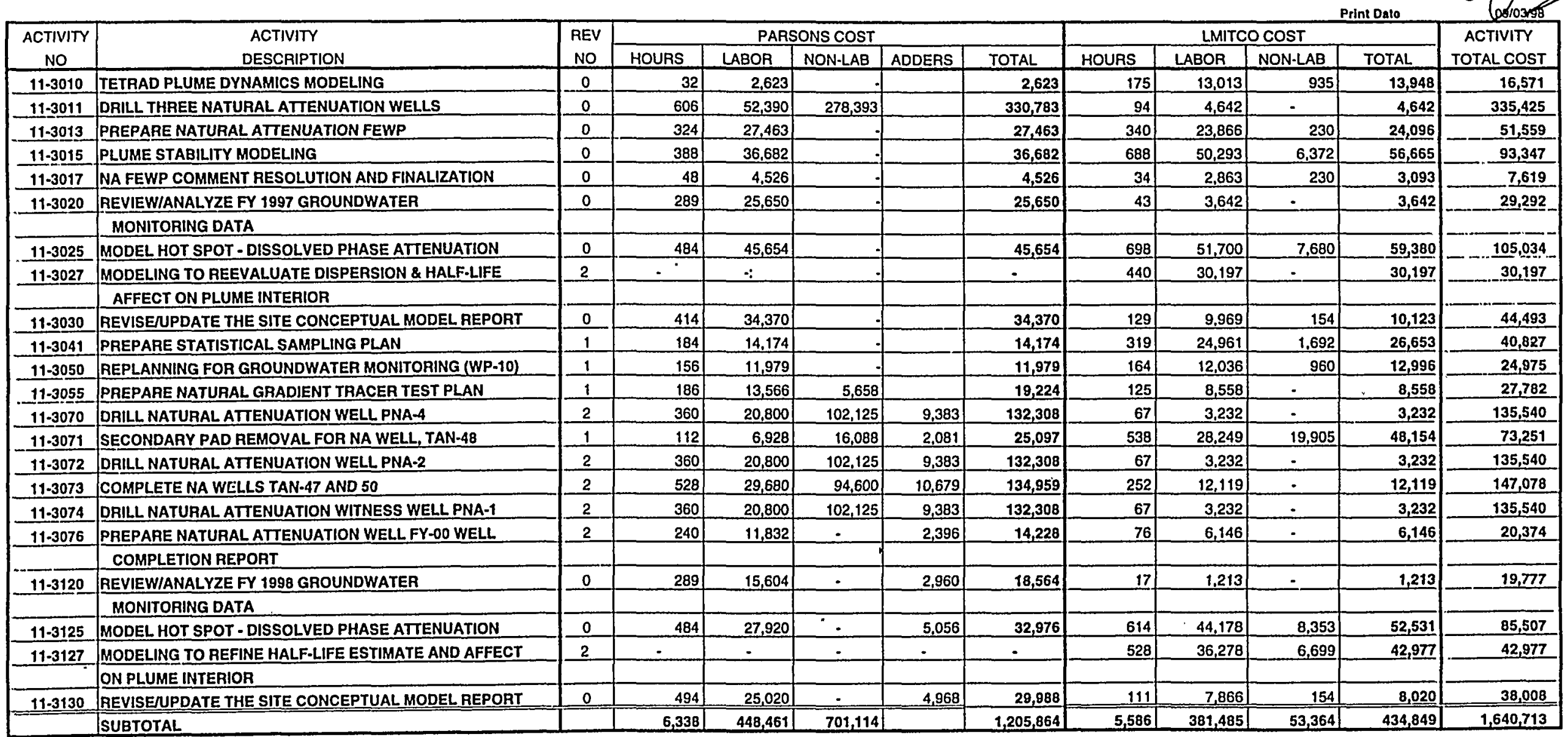




\section{APPENDIX C}

\section{Letters of Commitment from}

Implementing and Deploying Sites 


\title{
memorandum \\ Idaho Operations Office
}

\author{
Date: March 4, 1999
}

Subject: Commitment to Implement Bioremediation and Natural Attenuation for In Situ Restoration of Chloroethene-Contaminated Groundwater at the INEEL - (OPE-ER-35-99)

\section{To: ASTD Program Office}

Thank you for partnering with us to implement Bioremediation and Natural Attenuation for In Situ Restoration of Chloroethene-Contaminated Groundwater at the Idaho National Engineering and Environmental Laboratory (INEEL). As the lead site for the deployment project, we are committed to executing this project as described in the attached deployment plan. In keeping with the ASTD programmatic objectives, our goal is to meet all identified cost, scope, and schedule performance measures. The following joint ownership, coordination, and performance measures have been identified in the deployment plan.

Projected Cost Savings: As detailed in the attached Deployment Plan, the baseline cost of this remedial action was estimated at $\$ 48,303 \mathrm{~K}$. Due to enhanced in situ bioremediation and natural attenuation's lower operating and maintenance costs, we anticipate completing the clean up at a cost of $\$ 34,310 \mathrm{~K}$, for an anticipated cost savings of $\$ 13,993 \mathrm{~K}$.

Implementation Phase Scope and Schedule: Bioremediation and natural attenuation for in situ restoration of chloroethene-contaminated groundwater will be implemented at Test Area North at the INEEL. The qualification phase has been completed (funded by EM-40). We will commence the implementation phase upon approval of a technology task plan prepared after the deployment plan. Coupling enhanced in situ bioremediation with monitored natural attenuation will reduce the baseline pump and treat schedule for the hot spot by as much as 50 percent. Monitored natural attenuation of the dissolved phase portion of the plume will reduce overall operating and maintenance costs although it would likely be deployed over the entire restoration time frame.

Site Funding Contribution: Our Office of Environmental Restoration will be contributing matching funds in an equal amount to ASTD. Specifically, they will provide $\$ 286 \mathrm{~K}$ for the in situ bioremediation field evaluation; $\$ 525 \mathrm{~K}$ for installation of natural attenuation monitoring wells; $\$ 150 \mathrm{~K}$ for collection and analysis of natural attenuation samples; $\$ 359 \mathrm{~K}$ for deployment of ISB/NA at the INEEL; and \$180 for deployment integration with other DOE sites.

We are looking forward to cooperating with ASTD on this deployment project.

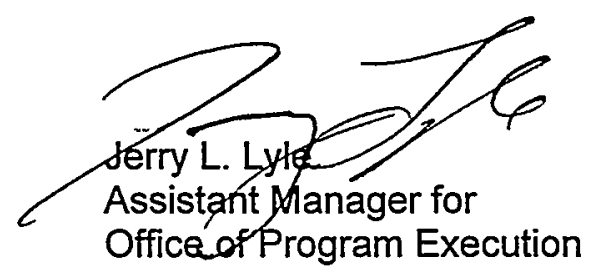

Attachment 


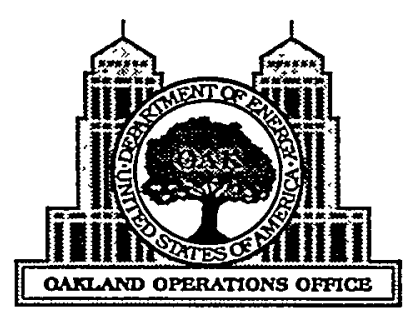

\section{TDI Program}

INEEL

P.O. Box 1625

Idaho Falls, ID 83415

\section{Dear TDI Program,}

The DOE Oakland Operations Office commits to deploying In Situ Bioremediation/Natural Attenuation at Operable Unit Site 300, Building 834 beginning in F'Y00, assuming it successfully completes the Qualification and Implementation phases as described in the project deployment plan. Implementing In Situ Bioremediation/Natural Attenuation at Operable Unit Building 834 is estimated to result in an approximate cost savings of 9.6 million dollars (30-years-present value, $5 \%$ discount rate currently in the Site 300 Site Wide FS) over the current baseline while accelerating the site cleanup by approximately 20 years. We currently propose to re-invest the saved funding by applying it to Building 850, Pits 3 and 5 which will accelerate progress toward our Accelerated Cleanup: Path to Closure baseline.

At the conclusion of the Qualification phase, we will provide a copy of the Change Control modifying and justifying the Operable Unit Building 834 site work plans to incorporate In Situ Bioremediation/Natural Attenuation into our baseline.

$$
\text { Sincerely, }
$$

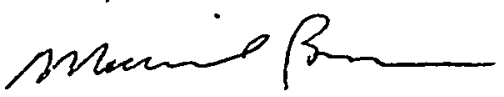

ivije Brown

Deputy Division Director

Environmental Restoration Division

DOE/OAK

cc:.$K$. Abbott

K. Angleberger

D. Bishop

A. Lamarre

R. Liddle

A. Osorio

E. Reber-Cox

J. Steenhoven

MGB:RH:hkb

99-1/29-004 
DATE: March 5, 1999

REPLY TO

ATTN OF: EM-93:Phillips

SUBJECT: MEMORANDUM OF INTEREST FOR TECFYOLOGY DEPLOYMENT INITIATIVE PROJECT

TO: Nolan R. Jensen, Idaho Operations Office

I am writing to express the interest of the Oak Ridge Operations (ORO) Office in the Idaho . National Engineering and Environmental Laboratory (NEEEL) Technology Deployment Initiative (IDI) proposal which addresses the In-Situ Bioremediation of chlorinated solvents. The Oak Ridge Reservation (ORR) has a need for remedial altematives for the environmental restoration of several groundwater plumes contarninated with chlorinated volatile organic compounds.

The Oak Ridge Site Office is intercsted in becoming a follow-on deployment site for your TDI proposal titled "In Situ Bioremediation". This proposal has significant potential application at the ORR.

I hereby commit to further investigating this proposal's application and cost-effectiveness for deployment at the ORR based upon information gathered during the implementation phase of the rechnology. Tommy Phelps and collaborating scientists will support this effort by participating in the planning of the project, and by monitoring progress and analyzing results. These efforts are to facilitate the transition from the implementation site to the deployment site and to ensure that the technology, as implemented, meets our aeeds.

We look forward to working with IVEEL on the IDI project. We are confident that the Oak Ridge Site has the ability to deploy this technology once it has been demonstrated at the : implementing site.

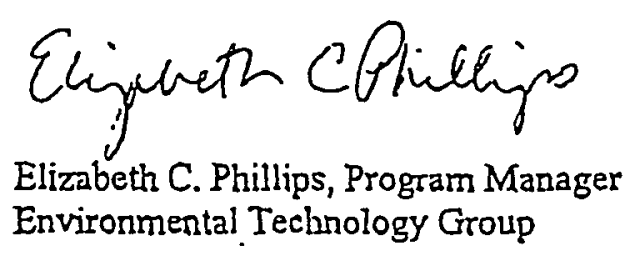

cc:

Cayanaugh Mims, EM-93

Jacquie Noble-Dial, EM-93

Gary Riner, EM-914

Gary Jacobs, Bldg. 1501, MS 6032 
Letters of commitment have been prepared by both the Paducah Gaseous Diffusion Plant and the Portsmouth Gaseous Diffusion Plant, but had not been received by the INEEL Implementation Team when this deployment plan went to press. Letters from these sites that were previously submitted in the proposal are included in lieu of the current letters. 


\section{imemorandum}

oure

Nerer ro

ATrk on

$\operatorname{sen}$

$\pi$

May 6, 1997

EF-2Z:MRRedfield

\section{LEITER OF INTEREST FOR TECHNOLOGY DEPLOYMENT DNTIATTVE (IRD PROJECT}

Nolan Jeosen, Manager, Enviroamental Restoration Program, Department of Energy (DOE), Idatio Operations Office, Idato Falls, Idzho

The Paducah Site Offle is interested in becoming 2 follow-on deployment site for your IDI proposal titied "In SIru Bioremediatlon." This proposal has potential applieation at the Padueah Gascous Diffusion Plant (PGDP).

I hereby commit to further investigating this proposal's application and cost-effectiveness for deployment at PGDP besed upon information gathered during the impleonentation phase of the - technalogy. We will support this effort by participating in the planning of the project, and by monitoriag progress and analyzing results. These cfforts are to facilizte the transition from the implesnentation site to the deployment site and to ensure that the technologs, 25 implernented, meess our reeds.

We look forward to worting with the Idaho National Engineering and Environmental Laboratory (INEE]) on the TDI project. We are confident that the Paducah Site bas the ability to deploy this technology once it has been demonserated at the implemerting site.

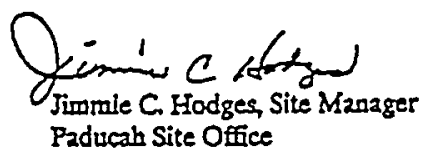

Paducah Site Office 
OATE: May 8, 1997

IEPLYTTO

ITN OF:

EF-21:Sheppard

AIBSECT:

MEMORANDUM OF INTEREST IN THE INEEL TECHNOLOGY DEPLOYMENT

ro: INITLATIVE (IDI) IN-SITU BIO-REMEDLATION

Nolan R. Jensen, Environmental Restoration Program Manager, Idaho Operations Office

I am writing to express the interest of the Portsmouth Site Office in the INEEL TDI proposal which addresses the In-Situ Bio-Rernediation of chlorinated solvents. Portsmouth has a need for remedial alternatives for the environmental restoration of five groind water plumes contaminated with cblorinated volatile organic compounds (YOCs). Pending the selection of your IDI proposal and performance evaluation of the process with regard to compliance standards, regulatory acceptability, cost effectiveness and the ability to achieve acceptable schedules, Portsmourb is comrnitted to the support and utilization of the IDI.

Please keep me apprised of the details of your deployment plan. My office is willing to support this effort by participating in project planning, monitoring progress, and reviewing your restults. If you have questions regarding this memorandum of interest, please contact John Sheppard (614-897-5510) of my staff.

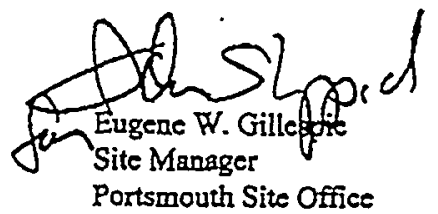

cc: Robert Sleeruan, EW-91/ORO 


\section{Appendix D}

\section{Project Tables}




\section{Bioremediation And Natural Attenuation For In Situ Restoration Of Chloroethene-Contaminated Groundwater Project Table}

Task 1. Microbial Community Characterization

\begin{tabular}{|c|c|c|c|c|c|c|c|}
\hline Task and Activity & Status & Performance Expected & Due Date & Actual Performance & $\begin{array}{l}\text { Actual Date } \\
\text { Completed }\end{array}$ & $\begin{array}{l}\text { Milestone/ } \\
\text { Deliverable }\end{array}$ & References and Comments \\
\hline $\begin{array}{l}\text { Task } 1.1 \\
\text { Collection of quarterly } \\
\text { samples from ARD } \\
\text { zone }\end{array}$ & $50 \%$ & $\begin{array}{l}\text { Sample Wells TAN-25, } 26 \text {, } \\
28,31,37 \text { once per quarter }\end{array}$ & $9 / 30 / 99$ & $\begin{array}{l}1^{\text {st }} \text { and } 2^{\text {nd }} \text { quarter samples } \\
\text { collected }\end{array}$ & & $\begin{array}{l}\text { Letter } \\
\text { Report }\end{array}$ & Summarize sampling planned vs performed. \\
\hline $\begin{array}{l}\text { Task 1.3a } \\
\text { Conduct PLFA, SLB, } \\
\text { and PCR analysis from } \\
\text { ARD zone }\end{array}$ & & $\begin{array}{l}\text { Analyze filter samples from } \\
\text { TAN-25, 26, 28,31, 37once } \\
\text { per quarter }\end{array}$ & $9 / 30 / 99$ & & & $\begin{array}{l}2 . \\
\text { Data } \\
\text { Summary }\end{array}$ & $\begin{array}{l}\text { The data summary will be included in the } \\
\text { Task } 1.4 \text { a report as an Appendix. }\end{array}$ \\
\hline $\begin{array}{l}\text { Task } 1.4 a \\
\text { Prepare ARD zone } \\
\text { Microbial } \\
\text { Characterization } \\
\text { Report }\end{array}$ & & $\begin{array}{l}\text { Conduct data analysis, } \\
\text { interpretation, and prepare } \\
\text { report }\end{array}$ & $9 / 30 / 99$ & & & $\begin{array}{l}\text { Technical } \\
\text { Report }\end{array}$ & \\
\hline $\begin{array}{l}\text { Milestone MS-1A } \\
\text { Submit TAN ARD } \\
\text { Zone Microbial } \\
\text { Characterization } \\
\text { Report }\end{array}$ & & $\begin{array}{l}\text { Submit Report to ASTD } \\
\text { during } 1^{\text {st }} \text { quarter FY } 2000\end{array}$ & $9 / 30 / 99$ & & & MS- $1 \mathrm{~A}$ & $\begin{array}{l}\text { Performing organization will complete report } \\
\text { by } 9 / 30 / 99 \text {, implementing site project team } \\
\text { will review and submit to ASTD during } 1^{\text {st }} \\
\text { quarter FY } 2000 \text {. }\end{array}$ \\
\hline $\begin{array}{l}\text { Task } 1.2 \\
\text { Collection of quarterly } \\
\text { samples from medial } \\
\text { zone }\end{array}$ & & $\begin{array}{l}\text { Sample Wells TAN- } 33,36 \text {, } \\
38,40,47,48,50,51,52 \\
\text { once per quarter }\end{array}$ & $9 / 29 / 00$ & & & $\begin{array}{l}3 . \\
\text { Letter } \\
\text { Report }\end{array}$ & Summarize sampling planned vs performed. \\
\hline $\begin{array}{l}\text { Task } 1.3 \mathrm{~b} \\
\text { Conduct PLFA, SLB, } \\
\text { and PCR analysis from } \\
\text { acrobic zone }\end{array}$ & & $\begin{array}{l}\text { Analyze filter samples from } \\
\text { TAN-40, } 39,38,33,36,48 \text {, } \\
51,52 \text { once per quarter }\end{array}$ & $9 / 29 / 00$ & & & $\begin{array}{l}4 . \\
\text { Data } \\
\text { Summary }\end{array}$ & $\begin{array}{l}\text { The data summary will be included in the } \\
\text { Task } 1.4 \mathrm{~b} \text { report as an Appendix. }\end{array}$ \\
\hline $\begin{array}{l}\text { Task } 1.4 \mathrm{~b} \\
\text { Prepare areobic zone } \\
\text { Microbial } \\
\text { Characterization } \\
\text { Report }\end{array}$ & & $\begin{array}{l}\text { Conduct data analysis, } \\
\text { interpretation, and prepare } \\
\text { report }\end{array}$ & $9 / 29 / 00$ & & & & \\
\hline $\begin{array}{l}\text { Milestone MS-1B } \\
\text { Submit TAN Aerobic } \\
\text { Zone Microbial } \\
\text { Characterization } \\
\text { Report }\end{array}$ & & $\begin{array}{l}\text { Submit Report to ASTD } \\
\text { during } 1^{\text {st }} \text { quarter FY } 2000\end{array}$ & $9 / 29 / 00$ & & & MS-1B & $\begin{array}{l}\text { Performing organization will complete report } \\
\text { by } 9 / 30 / 99 \text {, implementing site project team } \\
\text { will review and submit to ASTD during } 1^{\text {st }} \\
\text { quarter FY } 2000 \text {. }\end{array}$ \\
\hline
\end{tabular}


Bioremediation And Natural Attenuation For In Situ Restoration Of Chloroethene-Contaminated Groundwater Project Table

TASK 2: Natural Attenuation Monitoring Well Installation.

\begin{tabular}{|c|c|c|c|c|c|c|c|}
\hline Task and Activity & Status & Performance Expected & $\begin{array}{l}\text { Due } \\
\text { Date }\end{array}$ & Actual Performance & $\begin{array}{c}\text { Actual } \\
\text { Date } \\
\text { Completed }\end{array}$ & $\begin{array}{l}\text { Milestone/ } \\
\text { Deliverable }\end{array}$ & References and Comments \\
\hline $\begin{array}{l}\text { Task } 2.1 \\
\text { Installation of EM- } \\
40 \text { funded NA wells }\end{array}$ & & $\begin{array}{l}\text { Drill and complete two } \\
\text { NA wells, PNA-4 and } \\
\text { PNA-2 }\end{array}$ & $7 / 30 / 99$ & & & $\begin{array}{l}\text { Wells } \\
\text { Complete }\end{array}$ & $\begin{array}{l}\text { Two wells installed, } 97 / 8 \text { " open } \\
\text { hole, ready for sampling. }\end{array}$ \\
\hline $\begin{array}{l}\text { Task } 2.1 \mathrm{a} \\
\text { Installation of EM- } \\
40 \text { funded NA wells }\end{array}$ & & $\begin{array}{l}\text { Drill and complete one } \\
\text { NA well, PNA-1 }\end{array}$ & $4 / 28 / 00$ & & & $\begin{array}{l}\text { Well } \\
\text { Complete }\end{array}$ & $\begin{array}{l}\text { One well installed, } 97 / 8 \text { " open hole, } \\
\text { ready for sampling. }\end{array}$ \\
\hline $\begin{array}{l}\text { Task } 2.2 \\
\text { Installation of EM- } \\
50 \text { funded NA wells }\end{array}$ & & $\begin{array}{l}\text { Drill and complete two } \\
\text { NA wells, PNA-3 and } \\
\text { PNA-5 }\end{array}$ & $6 / 9 / 00$ & & & $\begin{array}{l}\text { Wells } \\
\text { Complete }\end{array}$ & $\begin{array}{l}\text { Two wells installed, } 97 / 8 \text { " open } \\
\text { hole, ready for sampling. }\end{array}$ \\
\hline $\begin{array}{l}\text { Milestone MS } 2 \\
\text { Complete five new } \\
\text { natural attenuation } \\
\text { monitoring wells }\end{array}$ & & $\begin{array}{l}\text { Five new NA wells } \\
\text { installed and available for } \\
\text { sampling. }\end{array}$ & $6 / 9 / 00$ & & & MS-2 & \\
\hline
\end{tabular}




\section{Bioremediation And Natural Attenuation For In Situ Restoration Of Chloroethene-Contaminated Groundwater}

Project Table

TASK 3. Natural Attenuation Monitoring.

\begin{tabular}{|c|c|c|c|c|c|c|c|}
\hline Task and Activity & Status & Performance Expected & $\begin{array}{l}\text { Due } \\
\text { Date }\end{array}$ & Actual Performance & $\begin{array}{l}\text { Actual } \\
\text { Date } \\
\text { Completed }\end{array}$ & $\begin{array}{l}\text { Milestone/ } \\
\text { Deliverable }\end{array}$ & References and Comments \\
\hline $\begin{array}{l}\text { Task 3.1 } \\
\text { Acquire depth- } \\
\text { discrete sampling } \\
\text { device }\end{array}$ & & $\begin{array}{l}\text { Prepare specification, } \\
\text { award contract, for new } \\
\text { multi-level sampling } \\
\text { device }\end{array}$ & $6 / 25 / 99$ & & & $\begin{array}{l}\text { Depth } \\
\text { discrete } \\
\text { sampler }\end{array}$ & $\begin{array}{l}\text { Reuseable, transportable, flexible } \\
\text { liner depth-discrete sampling } \\
\text { device, minimum of } 10 \text { sampling } \\
\text { ports. }\end{array}$ \\
\hline $\begin{array}{l}\text { Milestone MS - } 3 \text { A } \\
\text { Depth-discrete } \\
\text { sampler delivered } \\
\text { to INEEL }\end{array}$ & & $\begin{array}{l}\text { Sampling device delivered } \\
\text { to INEEL TAN and staff } \\
\text { trained. }\end{array}$ & $6 / 25 / 99$ & & & MS-3A & \\
\hline $\begin{array}{l}\text { Task } 3.2 \\
\text { FY } 1999 \text { Vertical } \\
\text { Profile Sampling }\end{array}$ & & $\begin{array}{l}\text { Collect/analyze depth- } \\
\text { discrete samples from } \\
\text { TAN-40,38, 47, 50, PNA- } \\
4, \text { PNA-2 }\end{array}$ & $10 / 22 / 99$ & & & $\begin{array}{l}5 . \\
\text { Letter } \\
\text { Report }\end{array}$ & $\begin{array}{l}\text { Summarize sampling planned vs } \\
\text { performed. }\end{array}$ \\
\hline $\begin{array}{l}\text { Task } 3.3 \\
\text { FY } 2000 \text { Vertical } \\
\text { Profile Sampling }\end{array}$ & & $\begin{array}{l}\text { Collect/analyze depth- } \\
\text { discrete samples from } \\
\text { TAN-40, 38, 47, 50, PNA- } \\
\text { 4, PNA-2, PNA-1 }\end{array}$ & $9 / 22 / 00$ & & & $\begin{array}{l}6 . \\
\text { Letter } \\
\text { Report }\end{array}$ & $\begin{array}{l}\text { Summarize sampling planned vs } \\
\text { performed. }\end{array}$ \\
\hline $\begin{array}{l}\text { Task } 3.4 \\
\text { FY } 2001 \text { Vertical } \\
\text { Profile Sampling }\end{array}$ & & $\begin{array}{l}\text { Collect/analyze depth- } \\
\text { discrete samples from } \\
\text { TAN-47, 50, PNA-1, 2, 3, } \\
4,5\end{array}$ & $8 / 24 / 01$ & & & $\begin{array}{l}7 . \\
\text { Letter } \\
\text { Report }\end{array}$ & $\begin{array}{l}\text { Summarize sampling planned vs } \\
\text { performed. }\end{array}$ \\
\hline $\begin{array}{l}\text { Milestone MS -3B } \\
\text { Submit Vertical } \\
\text { Profile Report }\end{array}$ & & $\begin{array}{l}\text { Prepare technical report } \\
\text { documenting results of } \\
\text { vertical profile data } \\
\text { analysis and } \\
\text { interpretation. }\end{array}$ & $9 / 21 / 01$ & . & & MS-3B & $\begin{array}{l}\text { Technical report summarizing } \\
\text { results of depth-discrete } \\
\text { sampling. }\end{array}$ \\
\hline
\end{tabular}


Bioremediation And Natural Attenuation For In Situ Restoration Of Chloroethene-Contaminated Groundwater-Project Table

TASK 4. Technology Integration And Deployment Process Linkage.

\begin{tabular}{|c|c|c|c|c|c|c|c|}
\hline Task and Activity & Status & Performance Expected & Due Date & Actual Performance & $\begin{array}{l}\text { Actual Date } \\
\text { Completed }\end{array}$ & $\begin{array}{l}\text { Milestone/ } \\
\text { Deliverable }\end{array}$ & References and Comments \\
\hline $\begin{array}{l}\text { Task } 4.1 \\
\text { Deployment Integration }\end{array}$ & & $\begin{array}{l}\text { Management, oversight, and } \\
\text { coordination between } \\
\text { implementing site and sites B } \\
\text { and } C \text {. }\end{array}$ & $9 / 28 / 01$ & & & $\begin{array}{l}\text { Monthly } \\
\text { Reports }\end{array}$ & $\begin{array}{l}\text { Provide routing status of project technical } \\
\text { progress through monthly reports. }\end{array}$ \\
\hline \multirow{3}{*}{$\begin{array}{l}\text { Task } 4.1 \text { a Technology } \\
\text { Information Exchange }\end{array}$} & & \multirow{3}{*}{$\begin{array}{l}\text { Annual presentation to } \\
\text { professional forum and/or } \\
\text { regulatory/stakeholder forum. }\end{array}$} & $9 / 30 / 99$ & $\cdot$ & & \multirow{3}{*}{$\begin{array}{l}11 / 12 / 13 \\
\text { Speaker } \\
\text { Materials }\end{array}$} & \multirow{3}{*}{$\begin{array}{l}\text { Presentation of enhanced ISB/MNA at } \\
\text { national/international forum and/or } \\
\text { regulatory/stakeholder forum at least once } \\
\text { per year }\end{array}$} \\
\hline & & & $9 / 28 / 00$ & & & & \\
\hline & & & $9 / 27 / 01$ & & & & \\
\hline $\begin{array}{l}\text { Milestone MS-4A } \\
\text { Technology Integration } \\
\text { and Deployment } \\
\text { Process Linkage } \\
\text { Complete }\end{array}$ & & Task 4.1 and 4.1 a complete & $9 / 28 / 01$ & & & MS- $4 \mathrm{~A}$ & \\
\hline \multirow{2}{*}{$\begin{array}{l}\text { Task } 4.2 \\
\text { Data Analysis }\end{array}$} & & \multirow{2}{*}{$\begin{array}{l}\text { Analyze and interpret } \\
\text { implementing site data. }\end{array}$} & $9 / 30 / 99$ & & & \multirow{2}{*}{$\begin{array}{l}9 / 10 . \\
\text { Letter } \\
\text { Report }\end{array}$} & \multirow{2}{*}{$\begin{array}{l}\text { Summary of data analysis results for FY } \\
1999 \text { and } 2000 .\end{array}$} \\
\hline & & & $9 / 29 / 00$ & & & & \\
\hline $\begin{array}{l}\text { Milestone MS-4B } \\
\text { Implementing Site data } \\
\text { analysis complete }\end{array}$ & & Task 4.2 complete. & $9 / 29 / 00$ & & & MS-4B & \\
\hline $\begin{array}{l}\text { Task } 4.3 \\
\text { Site Selection and } \\
\text { Qualification }\end{array}$ & & $\begin{array}{l}\text { Conduct workshop at INEEL } \\
\text { to select site } B \text { and } C \text {, prepare } \\
\text { summary report. }\end{array}$ & $7 / 2 / 99$ & & & $\begin{array}{l}8 . \\
\text { Letter } \\
\text { Report }\end{array}$ & $\begin{array}{l}\text { Summary of workshop meeting with } \\
\text { attachments of participating site } \\
\text { presentations. }\end{array}$ \\
\hline $\begin{array}{l}\text { Milestone MS-4C } \\
\text { Deployment sites B and } \\
\text { C selected }\end{array}$ & & Task 4.3 complete. & $7 / 2 / 99$ & & & $\mathrm{MS}-4 \mathrm{C}$ & Notification sent to selected sites. \\
\hline $\begin{array}{l}\text { Milestone MS-4D } \\
\text { Submit Sitc B Data Gap } \\
\text { Characterization } \\
\text { Report }\end{array}$ & & Site B qualification complete. & $9 / 29 / 00$ & & & MS-4D & $\begin{array}{l}\text { Performing organization will complete } \\
\text { report by } 9 / 29 / 00 \text {, implementing site } \\
\text { project team will review and submit to } \\
\text { ASTD during } 1^{\text {st }} \text { quarter FY } 2001 .\end{array}$ \\
\hline $\begin{array}{l}\text { Milestone MS-4E } \\
\text { Submit Site C Data } \\
\text { Gap Characterization } \\
\text { Report }\end{array}$ & & Site $\mathrm{C}$ qualification complete. & $9 / 26 / 01$ & & & MS-4E & $\begin{array}{l}\text { Performing organization will complete } \\
\text { report by } 9 / 26 / 01 \text {, implementing site } \\
\text { project team will review and submit to } \\
\text { ASTD during } 1^{\text {st }} \text { quarter FY } 2002 \text {. }\end{array}$ \\
\hline $\begin{array}{l}\text { Milestone MS-4F } \\
\text { Submit ROI Cost } \\
\text { Savings Report }\end{array}$ & & $\begin{array}{l}\text { Use data from Task } 4.2 \text { to } \\
\text { estimate long term operations } \\
\text { cost and ROI cost savings. }\end{array}$ & $3 / 30 / 01$ & & & MS-4F & $\begin{array}{l}\text { ROI cost savings report and supporting } \\
\text { data available for third party validation }\end{array}$ \\
\hline
\end{tabular}


Appendix E

Schedule and Logic Diagrams 


\section{Task 1}

Durallon Stant Finlsh Start Finsh

EM-50

1st Ouantor 1999: ColloctAnalyze PLFA somplos
Itom 5.7 wolls

2nd Quarter 1999: CollectAnalyze PLFA samples from 5.7 wolls

$1,0 \quad 4 / 5 / 99 \quad 4 / 9 / 90 \quad 4 / 5 / 99 \quad 4 / 9198$ 3rd Quartor 1999: ColloctAnalyze PLFA samples
Itom $5-7$ wolls $\begin{array}{llllll}1,0 & 4 / 12 / 99 & 4 / 16 / 99 & 4 / 12 / 99 & 4 / 16 / 99\end{array}$

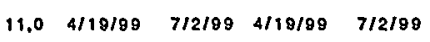
4th Quanter 1999: CollocyAnalyzo PLFA samples Itom 5.7 wells

$\begin{array}{lllll}12,4 & 7 / 5 / 99 & 9 / 30 / 89 & 7 / 5 / 99 & 9 / 30 / 99\end{array}$


$9 / 30 / 89 \quad 9 / 30 / 89 \quad 9 / 30 / 99 \quad 9 / 30 / 99$

Propare ARO Zone Mecroblat Charactorization Ropon $\begin{array}{lllll}12,4 & 7 / 5 / 99 & 9 / 30 / 99 & 7 / 5 / 90 & 9 / 30 / 98\end{array}$ Dotiverablo 2: Complato ARO zono data summary 8/30/99 $\quad 9 / 30 / 99 \quad 9 / 30 / 99 \quad 9 / 30 / 99$

\begin{tabular}{lll}
\hline MS-1A: Submil ARO ZOno Microblal Charactorization & $9 / 30 / 99$ & 9/30/98
\end{tabular}

MS-IA: Submil ARD Zone Microblal Charactorization
Roport

$13,1 \quad 10 / 1 / 99 \quad 12 / 31 / 99 \quad 10 / 1 / 99 \quad 12 / 31 / 99$ 1st Quartor 2000: Colloct'Analyzo PLFA samplos 2nd Quartor 2000: Colloct/Analyzo PLFA samplios

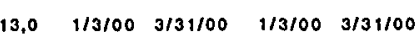
3rd Quarter 2000: Collect/Analyzo PLFA samplos 8.10 wols

$\begin{array}{llll}3,0 & 4 / 3 / 00 & 6 / 30 / 00 \quad 4 / 3 / 00 \quad 6 / 30 / 00\end{array}$ 4th Quartor 2000: Colloctinalyze PLFA samples $13,0 \quad 7 / 3 / 00 \quad 8 / 29 / 00 \quad 7 / 3 / 00 \quad 9 / 28 / 00$ Dollivorable 3: Lotlor Roport. FY 2000 Aoroblc Zono $\begin{array}{llll}9 / 29 / 00 & 9 / 29 / 00 & 10 / 1 / 00 & 9 / 30 / 00\end{array}$ Proparo Aorobic Zono Mitroblal Charactorization $\begin{array}{lllll}13,0 & 7 / 3 / 00 & 8 / 29 / 00 & 7 / 3 / 00 & 8 / 29 / 00\end{array}$ Dolvorablo 4: Completo Aoroble zono dota summary $0 / 29 / 00 \quad 0 / 29 / 00 \quad 9 / 20 / 00 \quad 9 / 29 / 00$

$\begin{array}{lll}\text { MS.18: Submit Aerobic Zone Microblal } & \text { 0/29/00 } & \text { 0/20/00 }\end{array}$
Charactorization Ropor

\section{Task 2}

EM-40

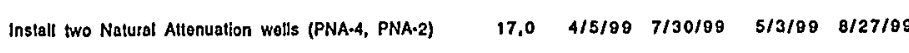
\begin{tabular}{llllll}
\hline Install ono Natural Attonuation woll (PNA-1) & 4,0 & $4 / 3 / 00$ & $4 / 28 / 00$ & $5 / 15 / 00$ & $6 / 9 / 00$
\end{tabular} EM-5O

Instaill two Natural Attonuation wells (PNA-3, PNA-5)

$6,0 \quad 5 / 1 / 00 \quad 6 / 9 / 00 \quad 6 / 12100 \quad 7 / 21 / 00$

MS-2: Complete Five now Natural Attenuation Wolls

$6 / 9100$

9/28101

Ost $\quad 2000$

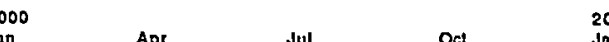
2001
Jan Apr $\quad$ Jul 
- ASTO Enhanced LSBMANA Deploymen

Output : Gantt Roport

Shool

Early Late

Duralion Start Finlsh Start Finlsh $\begin{gathered}1099 \\ \text { Apt }\end{gathered}$

\section{Task 3}

EM-40

Proparo SAP lor vortical profilo sampiling

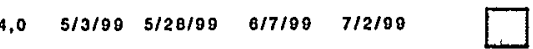
Analyzo FY 1099 vortical protilo samples

$16,0 \quad 7 / 5 / 89 \quad 10 / 22 / 89 \quad 7 / 10 / 00 \quad 10 / 27 / 00$ Dollverablo S: FY 1999 Vortical Profito Lottor Roport Analyzo FY 2000 vortical profilo samplos $10 / 22 / 99$ 10/22/89 9/28/01 9/28/01 $25,0 \quad 4 / 10 / 00 \quad 9 / 28 / 00 \quad 10 / 30 / 00 \quad 4 / 20 / 01$

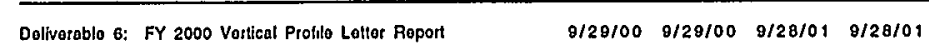
Analyze FY 2001 vertical protilo samplos Delivarablo 7: FY 2001 Vonlical Protilo Lotter Ropott $10,0 \quad 4 / 16 / 01 \quad 8 / 24 / 01 \quad 4 / 23 / 01 \quad 8 / 31 / 01$ $\begin{array}{lllll}8 / 24 / 01 & 8 / 24 / 01 & 9 / 28 / 01 & \text { 9/28/01 }\end{array}$ Proparo Vortical Profile Roport

$\begin{array}{llllll}12,0 & 7 / 2 / 01 & 0 / 21 / 01 & 7 / 0 / 01 & 9 / 28 / 01\end{array}$ MS.3B: Submil Vortical Profilo Roport $9 / 21 / 0$ $9 / 28 / 01$ EM-50

Procuro FLUTo vortical profllo sampler

$\begin{array}{lllll}12.0 & 4 / 5 / 99 & 6 / 25 / 99 & 4 / 12 / 99 & 7 / 2 / 99\end{array}$ MS-3A: Dopth discroto samplor dollvered to INEEL FY FY 1999: Colloet vortical p.otion
TAN-40, 38, PNA-4, PNA.2 FY 2000; Collect vertical protllo samplos trom TAN-40, 38, PNA-1, 2, 3, 4, 5 FY 2001: Colloct vortlcal profilo samplos from PNA-1, 2, 3, 4, 5

\section{Task 4}

EM. 50

Tochnology Intogration and Doploymont Process Linkago

$130,0 \quad 4 / 5 / 99 \quad 9 / 28 / 01 \quad 4 / 5 / 89 \quad 8 / 28 / 01$

MS-AA: Technology Integration and Deployment

Conduct Silo Soloccion Workshop at INEEC Deiverablo 8: Sito Soloction Roport MS-4C: Deptoyment Sites $B$ and C Solected


Implementing Silo: FY 1999 Data Anarysis Delverabbe 9: FY 1999 ISBMNA Data Summary

$\begin{array}{lllll}12,0 & 6 / 28 / 99 & 9 / 17 / 9 \theta & 7 / 5 / 99 & 9 / 24 / 9 \theta\end{array}$ $21,0 \quad 4 / 3 / 00 \quad 8 / 25 / 00 \quad 4 / 10 / 00 \quad 9 / 1 / 00$

$\begin{array}{llllll}15,0 & 4 / 8 / 01 & 7 / 20 / 01 & 4 / 16 / 01 & 7 / 27 / 0\end{array}$

!

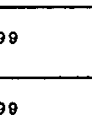

1
2000
jol

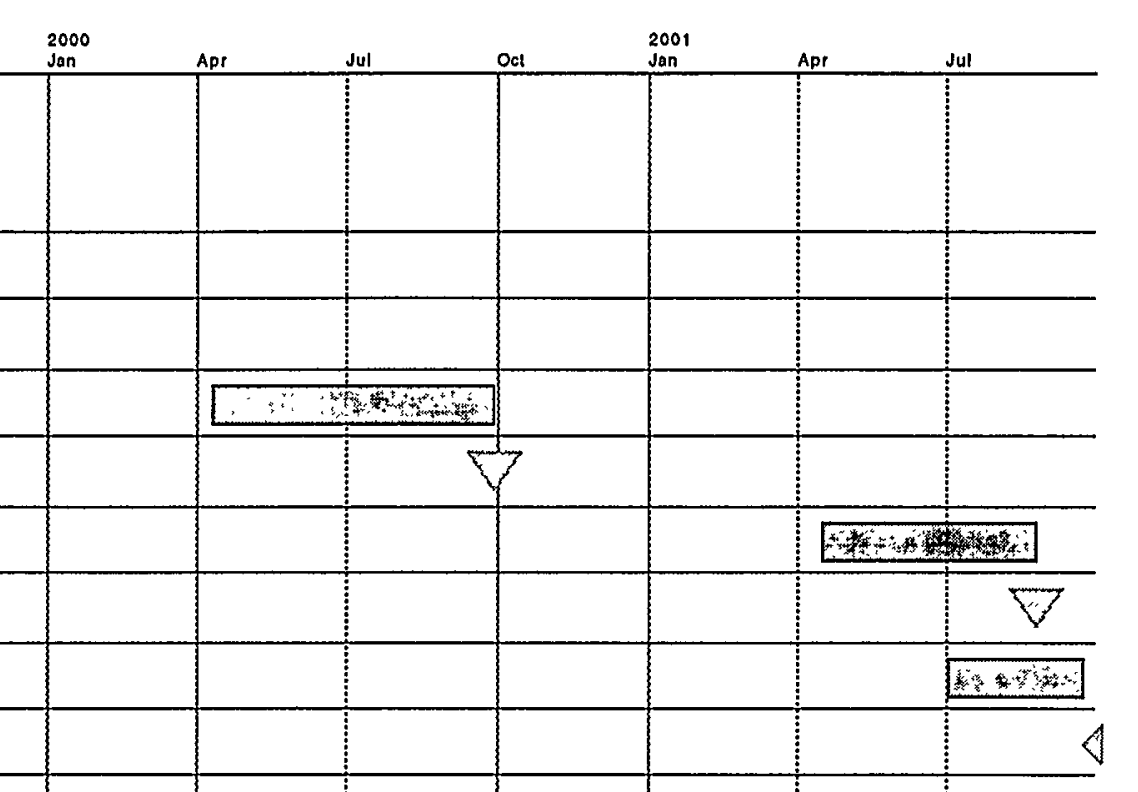




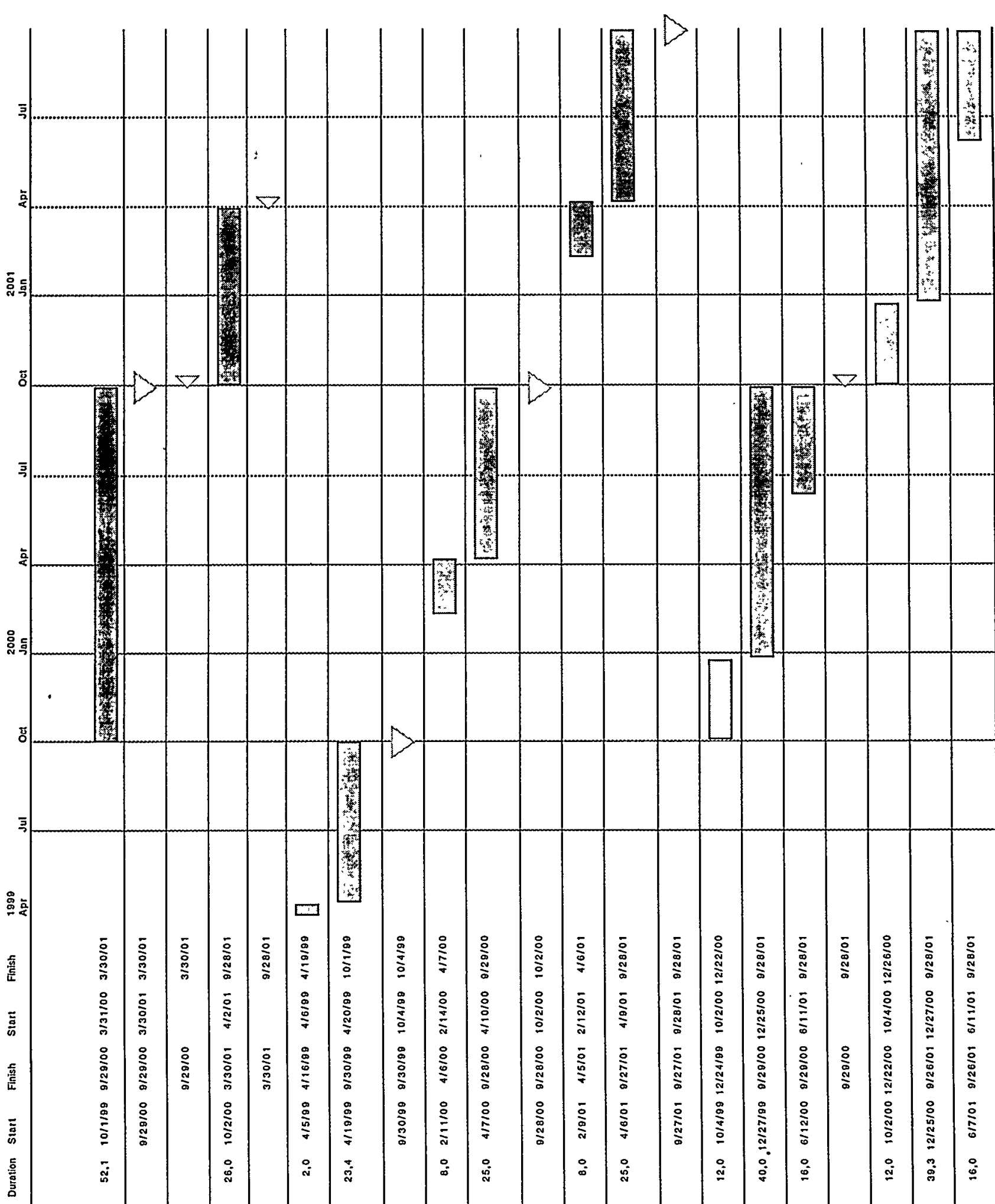





Output
ASTD Enhene
Gantt Ropart

4 of 4

Early

Lato

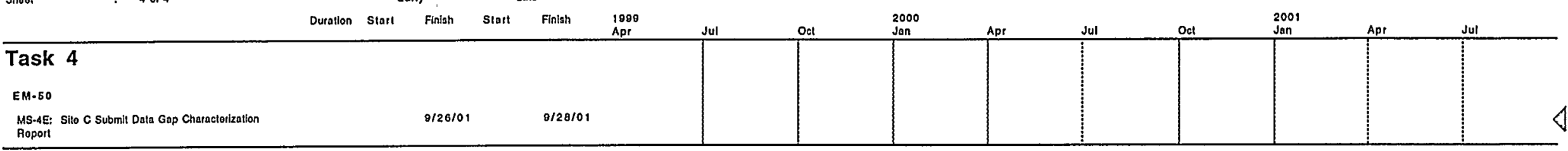

MS-4E: Sito C Submit Dota Gap Chatactorization
Roport

$8 / 26 / 01$ 


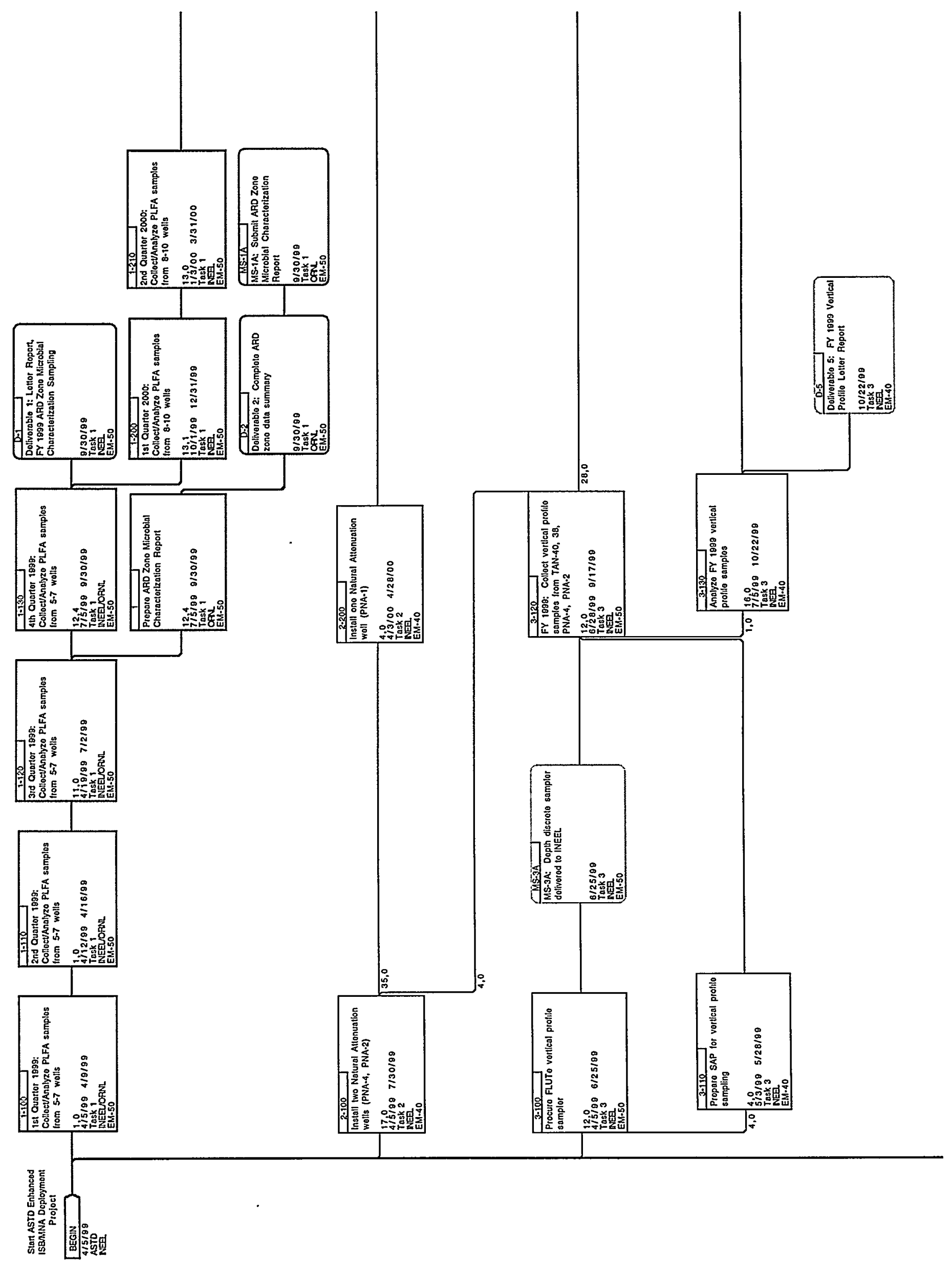




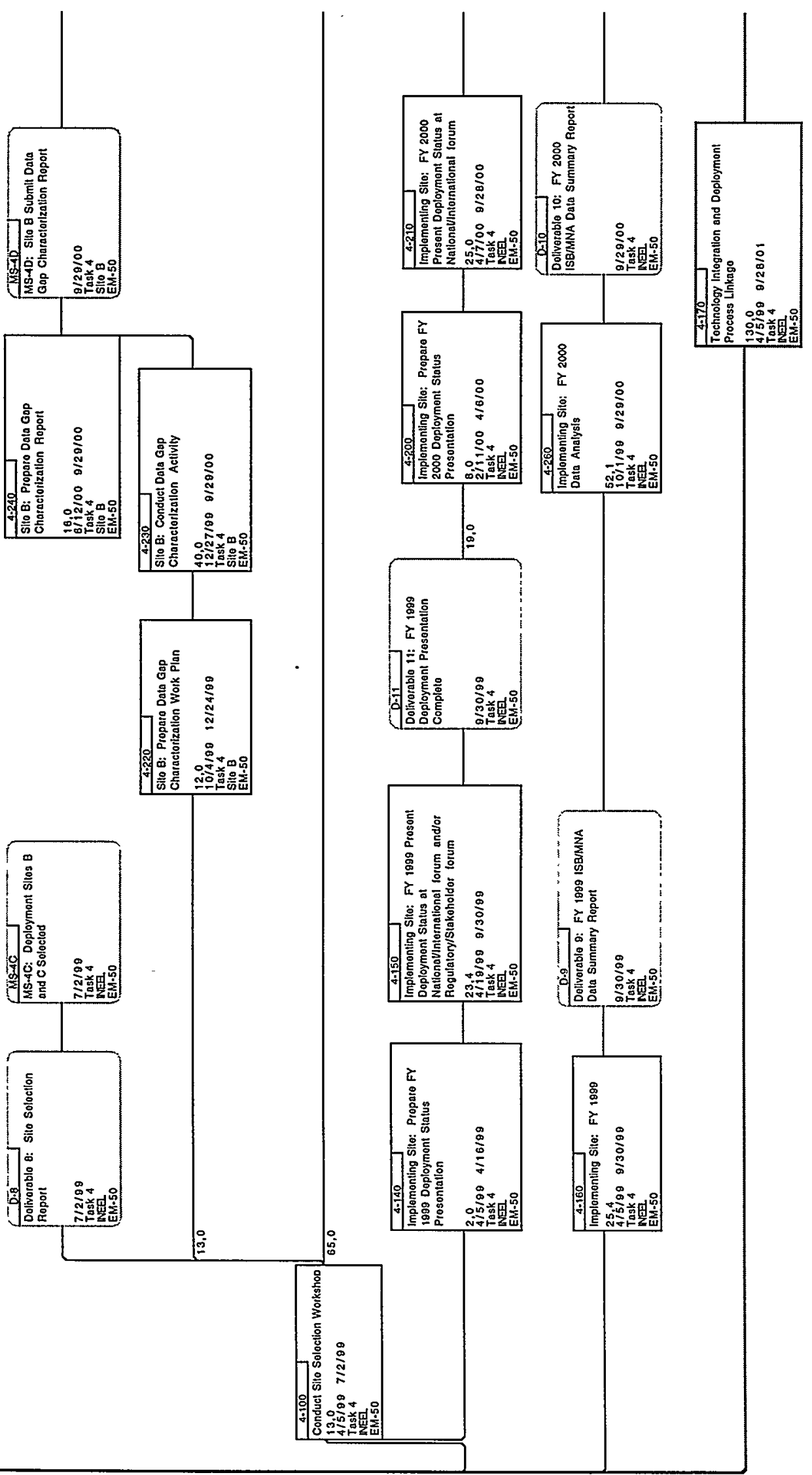




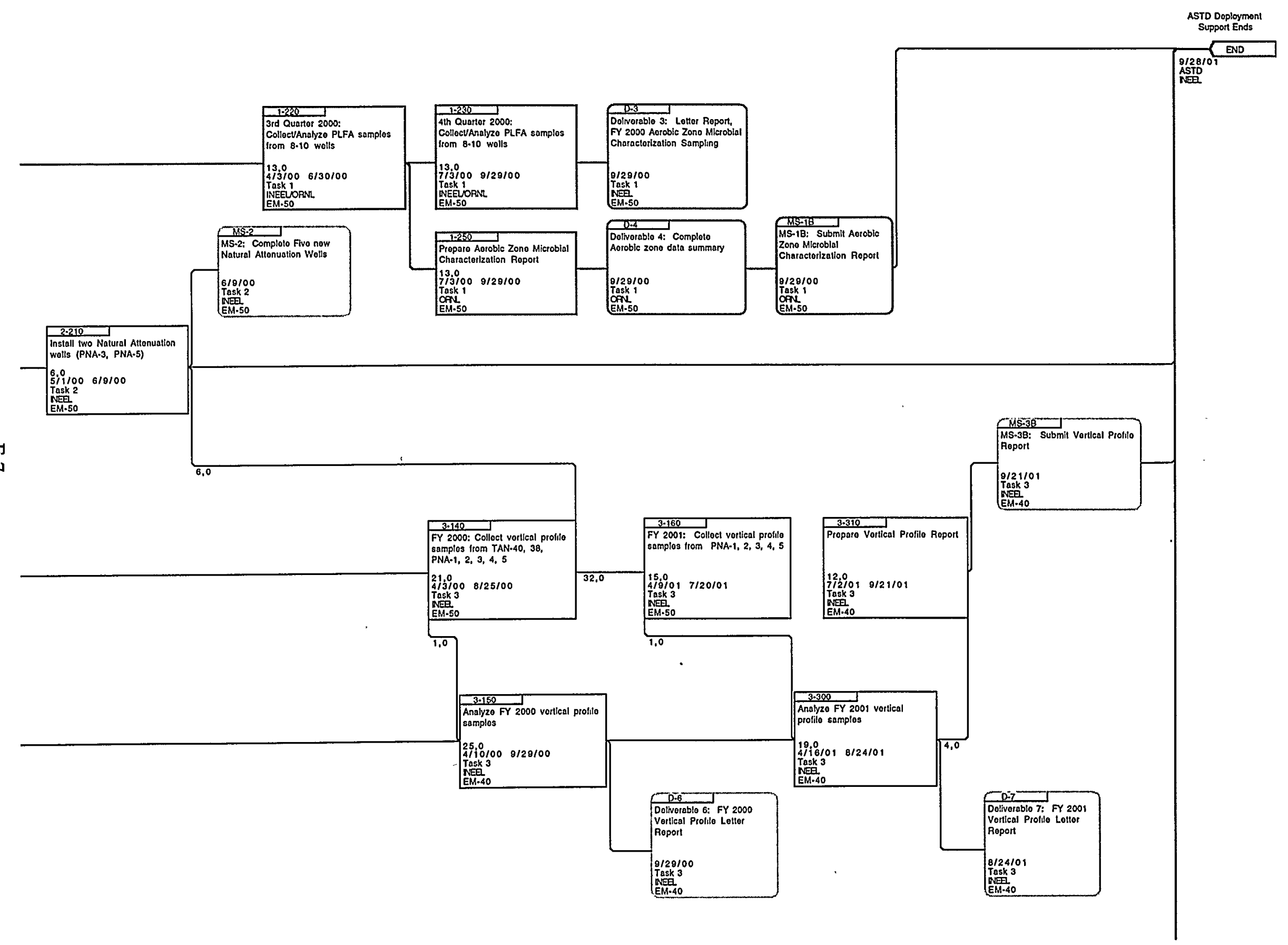




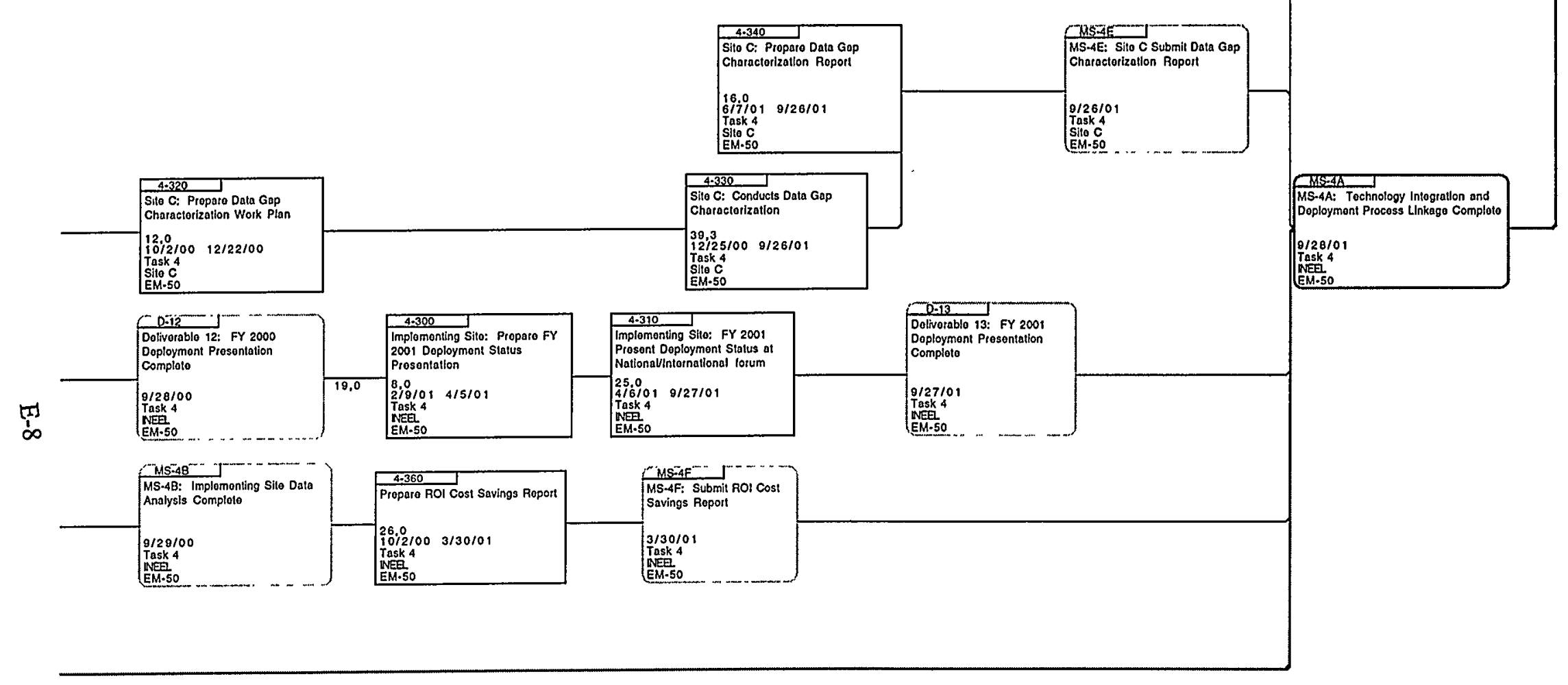

